\title{
Application of multi hydrochemical indices for spatial groundwater quality assessment: Ziway Lake Basin of the Ethiopian Rift Valley
}

\author{
Abraham Mechal ( $\nabla$ abrichyd2011@gmail.com ) \\ Addis Ababa Science and Technology Uinversity \\ Hassen Shube \\ Adama Science and Technology University \\ Tewodros Rango \\ Tulane University \\ Kristine Walraevens \\ Ghent Unversity

\section{Steffen Birk} \\ University of Graz
}

\section{Research Article}

Keywords: Ziway Lake Basin, Major ions, Trace elements, Water Quality Indices, Ethiopian Rift Valley

Posted Date: September 13th, 2021

DOl: https://doi.org/10.21203/rs.3.rs-227077/v1

License: (c) (i) This work is licensed under a Creative Commons Attribution 4.0 International License.

Read Full License

Version of Record: A version of this preprint was published at Environmental Earth Sciences on December 27th, 2021. See the published version at https://doi.org/10.1007/s12665-021-10135-5. 


\title{
Application of multi hydrochemical indices for spatial groundwater quality assessment: Ziway Lake Basin of the Ethiopian Rift Valley
}

\author{
Abraham Mechal ${ }^{1}$, Hassen Shube ${ }^{2}$, Tewodros Rango Godebo ${ }^{3}$, Kristine Walraevens ${ }^{4}$, Steffen Birk ${ }^{5}$ \\ ${ }^{1}$ Mineral Exploration, Extraction and Processing Center of Excellence, Addis Ababa Science Technology University, P.O. BOX 16417, Addis \\ Ababa, Ethiopia \\ ${ }^{2}$ Applied geology department, Adama Science Technology University, P.O. BOX 1888, Adama, Ethiopia \\ ${ }^{3}$ Department of Environmental Health Sciences, School of Public Health and Tropical Medicine, Tulane University, New Orleans, LA 70112, \\ United States \\ ${ }^{4}$ Laboratory for Applied Geology and Hydrogeology, Department of Geology, Ghent University, Krijgslaan 281 S8, 9000 Ghent, Belgium \\ ${ }^{5}$ Institute of Earth Sciences, University of Graz, NAWI Graz, Geo-center, Heinrichstraße26, A-8010, Austria
}

\begin{abstract}
The Ethiopian Rift Valley (ERV), which is characterized by arid and semi-arid climate, groundwater is the most important water resource used for drinking and irrigation purposes. However, in the region people are suffering from severe water scarcity exacerbated by climate effect. Besides water availability, endemic water quality issues are critical and affect the suitability of the water and human health risks. The present study evaluates the suitability of groundwater for drinking and agricultural purposes in the Ziway Lake Basin (ZLB) of the ERV. Groundwater used for drinking contains multiple inorganic contaminants in levels that surpass the World Health Organization recommended limits. The most frequent of these violations were for $\mathrm{Na}^{+}, \mathrm{K}^{+}, \mathrm{HCO}_{3}{ }^{-}, \mathrm{F}^{-}$and few samples for $\mathrm{Mn}, \mathrm{As}, \mathrm{U}, \mathrm{Pb}$ and $\mathrm{Mo}$. The modeled Drinking Water Quality Index (DWQI) values of the groundwater show wide variation ranging from 12.7 (Excellent category) to 714 (Unsuitable category) with mean value of 94. Likewise, Irrigation Water Quality Index (IWQI) computed by considering EC, SAR, Na\%, RSC and PI of the groundwater vary from 13.2 to 520 with mean value of 106. Both DWQI and IWQI value suggest that groundwater is generally of Excellent quality for drinking and irrigation use in the headwater regions of the ZLB and progressively becomes extremely Unsuitable towards the rift floor. The exceptionally high DWQI values to the west of Lake Ziway is mainly associated with the co-occurrence of multiple toxic elements from a groundwater from the Quaternary sediments and rhyolitic volcanic aquifers.
\end{abstract}

Key words: Ziway Lake Basin, Major ions, Trace elements, Water Quality Indices, Ethiopian Rift Valley 


\section{Introduction}

Groundwater represents more than $90 \%$ of the world's readily available freshwater resources (Boswinkel 2000) and has a vital role in supporting the life of mankind (WRI, UNEP, UNDP, World Bank 1998). As groundwater is less vulnerable to contamination than surface water and provides a buffer against climate change, it has been increasingly used as water source for human consumption, irrigation, and industrial water supply (Wada et al. 2014). However, getting enough water with the required quality to satisfy the demand for various purposes is one of the major challenges in the $21^{\text {st }}$ century (Amangabara and Ejenma 2012; Fienen and Arshad 2016).

The Ethiopian Rift Valley (ERV), a volcano-tectonically active part of the East African Rift system, provides an example of the challenges to water supply posed by groundwater quality. The ERV is about $1000 \mathrm{~km}$ long and 70-80 $\mathrm{km}$ wide, bordered by large and discontinuous normal fault systems (WoldeGabriel et al. 2000). As the rift margins are 2,000-3,000 $\mathrm{m}$ above the rift floor, the rainfall within the region is highly variable both in space and time. As a result, the available surface water resources are unreliable and not sufficient to fully support the sharply increasing population and socio-economic development in the region. Consequently, groundwater becomes the only dependable water resource for community water supply especially for the people residing in the semi-arid to arid section of the ERV. However, groundwater of the ERV has a significant water quality problem and does not comply with the established drinking water quality norms (Tekle-Haimanot et al. 1987; Tekle-Haimanot 1990; Kloos and TekleHaimanot 1999; Reimann et al. 2003). Several researchers (Chernet 1982; Darling et al. 1996; Ayenew 1998; Gizaw 1996; Yirgu et al. 1999; Chernet et al. 2001; Reimann et al. 2003; Tekle-Haimanot et al. 2006; Rango et al. 2010) noted that high salinity and fluoride levels appear to be the most widespread causes of water quality degradation in the region. According to Kassa (2007), the majority (80\%) of groundwater well failures and abandonment in the central ERV are linked to these causes. The poor water quality in the region seems to be linked to the mobilization of contaminants naturally occurring in the volcanic rocks and lacustrine sediments and thus the enrichment of groundwater, e.g. with toxic elements (As, U, Mo and B), as it flows from rift escarpments to rift valley floor (UNDP 1973; Darling et al. 1996; Gizaw 1996; Rango et al. 2009, 2010, 2013).

Elevated geothermal gradients and emergence of mantle gases (e.g., $\mathrm{CO}_{2}$ ) escaping through fault zones are very common and enhance silicate weathering (Darling et al. 1996; Mechal et al. 2017), further facilitating the release of major and trace elements. As a result, the tolerance limit of these elements is often exceeded in drinking water, and over 13 million people living in the ERV are at risk from continuous exposure to high levels of multiple naturally occurring toxic chemical elements in the groundwater they consume (Reimann et al. 2003; Rango et al. 2012). Therefore, it is of great concern to assess the quality of groundwater for human consumption and health risks as well as for sustainable economic development, particularly its suitability to agricultural production (irrigation).

Several hydrochemical studies (e.g., Reimann et al. 2003; Kebede et al. 2010; Rango et al. 2009, 2010, 2013) have attempted to assess the groundwater water quality by comparing individual water quality parameters with standard values based on their uses. However, this type of assessment is not capable of providing a comprehensive picture of groundwater quality especially when there is a co-occurrence of multiple water quality degraders for decision-makers who require concise information. Moreover, the existing studies were mainly based on data points focused on the rift 
axis and very little information is available about the extension of water quality problems in the areas towards to the escarpment of the rift. As a result, the groundwater of ERV is crudely considered as unfit for any purposes. It thus is essential to assess the overall water quality status at basin wide scale to identify the most suitable areas for the development of groundwater resources for desired purposes.

Analyses of surface and groundwater chemistry have been widely used to determine the water quality status. Water Quality Indexes (WQIs), based on the chemical composition of the water, are efficient techniques to determine the overall water quality by aggregating several water quality parameters into a single number that helps managers and decision makers (Gebrehiwot et al. 2011;Rajankar et al. 2010; Ravikumar et al. 2013; Ocampo-Duque et al. 2006; Sutadian et al. 2016). Nowadays, several types WQIs have been formulated and, in particular, used to determine the suitability of groundwater for drinking purposes (Drinking Water Quality Index, DWQI) by many authors (Babiker et al. 2007; Singh and Khan 2011; Selvam et al. 2013; Sutadian et al. 2016; Boateng et al. 2016; RamyaPriya and Elango 2018).

The hydrochemical constituents of irrigation waters can have negative impacts on crop production and soil fertility (e.g., Singh et al. 2018). The projected results of IPCC (2013) suggest that the combined increase in evaporation and variability in rainfall over ERV due to global warming might lead to stress in surface water availability and quality. As a result, groundwater can potentially substitute for unreliable surface water supplies for irrigation, especially under climate change, and thus evaluation of the groundwater suitability for agricultural purposes is essential for future use of the water resource. There are many hydrochemical indices used to study the quality of water for irrigation (e.g., Abbasnia et al. 2018; RamyaPriya and Elango 2018): Electrical Conductivity (EC), Sodium Percentage (Na \%), Sodium Adsorption Ratio (SAR), Residual Sodium Carbonate (RSC), Permeability Index (PI), and Irrigation Water Quality Index (IWQI).

To enhance the understanding of the spatial variability of water quality and support the identification of groundwater resources suitable for drinking or irrigation purposes within the ERV, this work examines the example of Ziway Lake Basin (ZLB). The prime objective of this research is to: (1) assess the spatial distribution of major and trace element concentrations in the groundwater, (2) evaluate the suitability of groundwater for drinking and agricultural purposes, and (3) finally develop water quality maps of ZLB that will help for easy identification of areas for remediation and development of the groundwater resource.

\section{Study area}

\subsection{Location, physiography and climate}

The study area, ZLB, lies in the northern sector of ERV with an aerial extent of 7,291 km², out of which $430 \mathrm{~km}^{2}$ is covered by Lake Ziway (Fig. 1). Geographically, it is bounded between $7.36^{0}-8.47^{0} \mathrm{~N}$ latitude and $38.22^{0}-38.4^{0} \mathrm{E}$ longitude.

In the ZLB, two prominent physiography regions exist, namely: the rift floor $(<2,000$ meter above sea level ( $\mathrm{m}$ a.s.l.)) and the adjoining escarpments $(2,000-4,181 \mathrm{~m}$ a.s.l.). Although, the altitude shows wide ranges, about $60 \%$ of the basin area belongs to the rift floor while the remaining $40 \%$ belongs to the bordering escarpment on either side of the 
rift floor. Lake Ziway occupies the center of the rift floor and is fed by the two major rivers Ketar and Meki originating from the Eastern and Western flanks of the rift escarpments, respectively (Fig.1).

The climate of ZLB varies greatly from semi-arid in the rift floor to humid in the bordering escarpment. The long term (1981-2010) average annual rainfall of the study area is estimated to be $880 \mathrm{~mm} / \mathrm{year}$ (Frdisa 2019). Nevertheless, in the escarpment bounding the rift floor precipitation surpasses $1,200 \mathrm{~mm} / \mathrm{year}$, whereas at the lowest altitude in the rift floor rainfall is frequently below $625 \mathrm{~mm} /$ year. Mean monthly temperature varies from $21.8^{\circ} \mathrm{C}$ in the rift floor to less than $13.5{ }^{\circ} \mathrm{C}$ in the adjoining escarpments. The strong spatial variability of rainfall and temperature thus is explained by large differences in elevation.

\subsubsection{Geological and hydrogeological setting}

Being located in the heart of ERV, the geological setup of the study area, ZLB, is the result of different series of volcanic eruptions accompanied by tectonic events and denudation processes. The volcanic series and geological structures of the ERV have been extensively explored (Mohr 1962; Di Paola 1972; Merla et al. 1979; Kazmin et al. 1980; Woldegabriel et al. 1990; Di Paola et al. 1993; Boccaletti et al. 1998; Halcrow 2008; Dainelli et al. 2001; Benvenuti et al. 2002). Broadly, the outcropping lithology of the area can be subdivided into three major groups: Precambrian and Mesozoic sedimentary rocks, Volcanites and volcano-clastic rocks, and Quaternary Sedimentary deposits.

The Precambrian and Mesozoic sedimentary rocks cover very limited area in the northwestern part of the study area. They comprise Precambrian biotite gneiss overlain by layers of Mesozoic sedimentary successions (sandstones, shales, marls, and limestones). A large part of the ZLB is occupied by a variety of volcanic rocks in association with volcano-clastic sedimentary deposits. The adjacent escarpments comprise basaltic lava flows with inter-layered rhyolitic ignimbrite and tuff horizons. On the eastern side, these rock units are underlain by shield volcanoes comprising of mainly trachytes with subordinate basalts and phonolites. Most parts of the rift floor are covered by silicic pyroclastic materials mainly consisting of peralkaline rhyolitic ignimbrites, poorly welded ignimbrites, and pumice fall with minor basaltic lava flows. Overlying the rift volcanic series, recent Quaternary sediments occupy the lake margins. The volcanic rocks and sediments of the ZLB have undergone extensive faulting resulting from the prevailing tectonic activity (Fig. 1).

As can be understood from the geological map (Fig.1), the hydrogeology of the study area is highly heterogeneous as a result of variability in lithologic units and structures. Despite the complexity in lithology, the rock units can be grouped in to three major hydrostratigraphic units: Quaternary sediments, fractured and weathered volcanics, and volcanics with low permeability (Ayenew 1998; OWWDSE 2016).

The Quaternary sediments are highly permeable and thick (>30m) in the rift floor; whereas in the steep scarps of the escarpments, the sediments are almost nonexistent and of low permeability. The fractured and weathered volcanic units form the major regional aquifer system. These units include basalt, ignimbrite and in some places rhyolites with varying permeability that generally increases towards the rift floor due to the increasing intensity of fracturing. 
Volcanics mainly comprising highly welded ignimbrites, tuff, rhyolite and trachyte with very low permeability occupy large parts of eastern and western mountainous regions.

In the study area, groundwater generally flows to the rift center from the adjacent escarpments indicating a topographic driven process at regional and sub-regional scale (Ayenew 1998; Ayenew et al. 2008, 2009). As a result, the rift floor is considered as regional discharge area where perennial rivers, lake and springs exist. However, locally in the rift floor, groundwater flow is strongly influenced by geological structures manifested by wetlands, swamps, and thermal springs emerging from active faults.

\subsubsection{Groundwater use}

In ZLB, groundwater is used for different purposes, with the largest proportion going toward for human consumption. Groundwater provides drinking water for almost entire population in the region as surface water resources such as rivers and lakes nearby the community are seasonal and usually carry higher pathogenic risks due to fecal contamination. Groundwater sources for drinking use ranges from springs to deep wells. However, many groundwater wells are contaminated with high levels of fluoride and other naturally occurring toxic trace elements (As, U, Mo, and B) (Reimann et al. 2003; Rango et al. 2009, 2010). Major towns in the region are receiving somewhat treated water from rivers and high discharge springs (fresh water). In contrast, the vast rural community largely rely on untreated groundwater wells and experiencing dental fluorosis and skeletal fluorosis due to long time exposure of fluoride contaminated groundwater with clearly unknown health impacts of other toxic trace elements (Rango et al. 2012, 2014, 2017).

Agriculture activities are the main source of income for the majority of people living in the study areas; and hence, the overall economic growth of these areas is highly dependent on the success of the agriculture sector. Alongside surface water resource such as Meki and Katar rivers and Ziway lake, groundwater is also used in the region by small scale agro-industries, commercial irrigation, and floriculture farms. Irrigation is mainly sustained by surface water, but less than one quarter of the irrigated areas depend on groundwater (Rodriguez de Francisco 2008; Pascual-Ferrer et al. 2014). Agricultural practice in the region is highly tied with the unreliable wet season of a year. During the last years, irrigation agriculture has increased rapidly in the study areas using shallow and deep groundwater wells especially in the rift floor. But the exploitation of groundwater for irrigation use is highly hampered by high salinity (e.g., Na, Cl and B) (Rango et al. 2010, 2012).

Apart from the above mentioned uses, groundwater has immense importance for the existence of rift lakes and wetlands. According to local water agencies working in the areas of water resource development, there is high pressure on the water resource utilization in the study areas; especially, in case of drinking water supply and irrigation water utilization during dry seasons. This and related reasons have brought conflicts among community members in different parts of the study area (WWDSE 2016). To satisfy the demands of different groups and support economic development of water resources, further detailed water quality mapping specifically considering those parameters that are relevant for different purposes is needed. 


\section{Possible site for Fig. 1}

\section{Materials and methods}

\subsection{Water sampling and analysis}

Groundwater samples were collected systematically along NE-SW and E-W transects representing the major physiographic regions of ZLB. Accordingly, 55 representative groundwater samples from springs (10) and wells (45) were collected during the transition period between wet and dry season (November to December) of 2018. The sampling depth of the groundwater in wells generally increase from a few meters $(27 \mathrm{~m})$ below the ground surface in the mountainous escarpments towards the center of the rift with maximum depth of $300 \mathrm{~m}$. The locations of the sampling sites are presented in Fig.1.

During sample collection, inactive wells had been pumped for about 10-20 minutes to remove the standing water column in the well to make sure sampling of fresh groundwater and the samples were collected while pumping. Springs were sampled at their emerging place using a plastic syringe. All water samples were filtered with $0.45-\mu \mathrm{m}$ filter membrane and kept in clean and dry $100 \mathrm{ml}$ standard double caped HDPE plastic bottles. The water samples for cation and trace element analyses were acidified with ultra-pure $6 \mathrm{~N} \mathrm{HNO}_{3}$ to prevent precipitation / adsorption during storage. Field-based water parameters such as temperature, $\mathrm{pH}$, Total Dissolved Solids (TDS), and Electrical Conductivity (EC) were measured onsite.

Both major and trace elements analyses were carried out in the Institute of Geology and Geophysics laboratory, Chinese Academy of Sciences, Beijing China. Major ions ( $\mathrm{Na}, \mathrm{K}, \mathrm{Ca}, \mathrm{Mg}, \mathrm{F}, \mathrm{SO}_{4}, \mathrm{NO}_{3}$, and $\mathrm{Cl}$ ) were analyzed by ion chromatography using a Dionex DX-120 equipment. Samples with high $\mathrm{Na}^{+}(>75 \mathrm{mg} / \mathrm{l})$ concentrations were diluted to avoid oversaturation. Titration techniques were used to analyze total alkalinity $\left(\mathrm{HCO}_{3}\right)$. Arsenic (As) was analyzed by LC- 6500 atomic fluorescence photometer. Other trace elements ( $\mathrm{Li}, \mathrm{Be}, \mathrm{Sc}, \mathrm{Ti}, \mathrm{V}, \mathrm{Cr}, \mathrm{Mn}, \mathrm{Co}, \mathrm{Ni}, \mathrm{Cu}, \mathrm{Zn}, \mathrm{Ga}$, $\mathrm{Rb}, \mathrm{Mo}, \mathrm{Cd}, \mathrm{Sb}, \mathrm{Ba}, \mathrm{Pb}, \mathrm{Bi}, \mathrm{U}$, and $\mathrm{Sr}$ ) were measured by Inductively Coupled Plasma Mass Spectrometry (ICP-MS) using NexION300D ICP/MS equipment. During the trace element analysis, a blank and two water standards were run at the start and end of the analyses. Measurement uncertainties for all parameters were evaluated and controlled using regular laboratory duplicates of samples and verifying the precision/calibration of the instruments through regular runs of various primary standard solutions.

\subsection{Drinking Water Quality Index (DWQI)}

DWQI presents the overall picture of water quality status for drinking purposes (Amiri et al. 2016; Herojeet et al. 2016; Darvishi et al. 2016). It converts selected water quality parameters into a single dimensionless number so that the water quality of different sources and sites can be evaluated and compared. The calculation procedure was described in detail by many researchers (e.g., Brown et al. 1972; Saeedi et al. 2010; Abbasi and Abbasi 2012) and generally involves four steps (Sutadian et al. 2016). In the first step, the water quality parameters to be included in the DWQI calculation are selected. Here, thirty five water quality parameters were analyzed. However, only 16 parameters (pH, EC, $\mathrm{Ca}, \mathrm{Mg}, \mathrm{Na}, \mathrm{K}, \mathrm{HCO}_{3}, \mathrm{Cl}, \mathrm{SO}_{4}, \mathrm{NO}_{3}, \mathrm{~F}, \mathrm{As}, \mathrm{Mn}, \mathrm{Mo}, \mathrm{U}$, and $\mathrm{Pb}$ ) that have great influence on water quality for drinking purpose were considered (Table 1). 


\section{Possible site for Table 1}

In the second step, each of the chemical parameters was assigned a weight $\left(\mathrm{AW}_{\mathrm{i}}\right)$. Unequal weight (Brown et al. 1970) was assigned based on their relative importance in the overall quality of water for drinking uses (Table 1). The assigned weight ranges from 1 to 5 . The highest weight of 5 was assigned to parameters which have the major effects on drinking water quality $\left(\mathrm{F}, \mathrm{As}\right.$, and $\left.\mathrm{NO}_{3}\right)$ and a minimum of 1 was assigned to parameters $(\mathrm{K})$ which are considered as not harmful (Srinivasamoorthy et al. 2008; Vasanthavigar et al. 2010). Other parameters were assigned a weight between 1 and 5 based on their importance in the overall quality of water for drinking uses (Table 1; Ketata-Rokbani et al. 2011). Finally, the Relative Weight (RW) of each parameter was calculated:

$$
R W=\frac{A W_{i}}{\sum_{1}^{n} A W_{i}}
$$

where $\mathrm{AW}_{\mathrm{i}}$ is the Assigned Weight of each parameter, $\mathrm{n}$ is the number of parameters and $\mathrm{RW}$ is the Relative Weight. The Assigned Weight (AW) and the calculated Relative Weight (RW) values are presented in Table 1.

In the third step, a quality rating scale $\left(\mathrm{Q}_{\mathrm{i}}\right)$ is calculated for each parameter:

$$
Q_{i}=\left[\frac{C_{i}}{S_{i}}\right] * 100
$$

where $\mathrm{Q}_{\mathrm{i}}$ is the quality ranking, $\mathrm{C}_{\mathrm{i}}$ is the concentration of each parameter in individual water sample in $\mathrm{mg} / \mathrm{l}$ and $\mathrm{S}_{\mathrm{i}}$ is the WHO standard for each parameter in $\mathrm{mg} / \mathrm{l}$ (Table 1).

Finally, in the fourth step, after the water quality sub-index $\mathrm{SI}_{\mathrm{i}}$ was obtained by multiplying the quality grade by the RW of each parameter (Eq. (3)), the integrated DWQI was obtained by totaling all the sub-indices (Eq. (4)).

$$
\begin{aligned}
& S I_{i}=R W * Q_{i} \\
& D W Q I=\sum_{i=1}^{n} S I_{i}
\end{aligned}
$$

\subsection{Irrigation water quality}

The quality of irrigation water has a substantial impact on the soil salinity, growth, and yield of agricultural products. In general, water applied for irrigation always contains different concentrations of dissolved constituents originating through natural (rainfall, weathering, and dissolution of rocks and soils) and anthropogenic (domestic and industrial) processes (Jarvie et. al. 1998). Therefore, the quality of the irrigation water needs to be assessed to avoid or reduce adverse impacts on agriculture (Mohammed 2011). The irrigation suitability of the groundwater was tested based on SAR in association with EC values, Na \%, RSC, and PI as calculated by the following formulas (Table 2).

In addition to the above indices, IWQI was computed to determine the overall suitability of the groundwater for irrigation based on several water quality parameters (Table 3 ). IWQI concept was primarily developed and introduced by Meireles et al. (2010) and later used by several authors (e.g., Abbasnia et al. 2018). However, in this study, IWQI model used by RamyaPriya and Elango (2018) which is similar to the assessment procedure applied in DWQI. Five 
parameters including EC, SAR, Na (\%), RSC, and PI, which dominantly influence the water quality for irrigation purpose were considered for computing IWQI. The IWQI was calculated using Eq. (5).

$$
I W Q I=\sum_{I=1}^{n} R W_{n} * Q_{n}
$$

where $\mathrm{RW}_{\mathrm{n}}=$ Relative Weight of the $\mathrm{n}^{\text {th }}$ parameter, $\mathrm{Q}_{\mathrm{n}}=$ sub-index of the corresponding parameter. The Assigned weights and sub-index of all the parameters computed and used are summarized in Table 3.

\section{Possible site for Table 2}

\section{Possible site for Table 3}

\section{Result and discussions}

\subsection{Hydrochemistry and drinking water quality assessment}

\subsubsection{Field-based parameters and major ions}

The analytical results of the physico-chemical parameters were statistically examined to provide the general chemical characteristics of the groundwater. Table 4 presents the minimum, maximum, mean, and the standard deviation for each variable. The permitted limits for drinking water set by WHO (2011) was included. For some elements that are not addressed by the guideline WHO (2011), US EPA (2003) was used for comparison purpose.

\section{Possible site for Table 4}

Field-based variables such as temperature, $\mathrm{pH}$, TDS, and EC of the groundwater show wide variability across the basin; however, a clear spatial pattern is observed from the escarpment towards the rift floor (Table 4; Fig. 2 (a-d)). The temperature of the groundwater varied from 14.3 to $60.7^{\circ} \mathrm{C}$. The $\mathrm{pH}$ of the groundwater varied from slightly acidic to slightly alkaline, ranging from 6.17 to 8.8 . TDS of the groundwater varied between 25 and 4,725 mg/l; whereas EC ranged from 38.75 to $6,300 \mu \mathrm{S} / \mathrm{cm}$. In general, temperature, $\mathrm{pH}$, TDS, and EC of the groundwater show a steady increase from the escarpment to the rift floor (Fig. 2 (a-d)) with local anomalies associated to thermal waters. This is attributed to strong water-rock interaction along the groundwater flow direction assisted by high geothermal gradient prevailing in the area (Darling et al. 1996; Gizaw 1996; Mechal et al. 2017).

Water samples collected from high altitudes (Western and Eastern escarpments) are characterized by low TDS and EC fully complying with the WHO (2011) drinking water quality guideline (Fig.2(c-d)). The high rainfall rate in the escarpment plays a main role in keeping the TDS and EC signature of the groundwater below the permissible value. However, in the rift floor more than $50 \%$ of the groundwater samples depicts high TDS and EC surpassing the permissible limit and are not suitable for drinking purposes. Almost all groundwater samples exhibited a $\mathrm{pH}$ value within the tolerable limit of 6.5-8.5 (WHO 2011), except a few acidic and alkaline groundwater samples situated in the upper escarpments and rift floor, respectively.

\section{Possible site for Fig. 2 (a-d)}


Unlike the field measured parameters, the main dissolved ions show a wide variability across the basin (Table 4; Fig $3(\mathrm{a}-\mathrm{h})$ ). The variation in cation concentrations is more evident than that of anions. $\mathrm{Mg}^{2+}$ ranged from below detection limit (bdl) to $33.4 \mathrm{mg} / \mathrm{l}$ with mean value of $7.3 \mathrm{mg} / \mathrm{l}$. On the other hand, $\mathrm{Ca}^{2+}$ concentration varied from 0.5 to 113.8 $\mathrm{mg} / \mathrm{l}$ with an average value of $28.9 \mathrm{mg} / \mathrm{l}$. Due to the weathering of olivine and pyroxene minerals in the source rocks (basalt), $\mathrm{Ca}^{2+}$ and $\mathrm{Mg}^{2+}$ are relatively predominant in the aquifers of the upper escarpment but gradually drop towards the rift floor. Both $\mathrm{Ca}^{2+}$ and $\mathrm{Mg}^{2+}$ concentration in the groundwater are within the permissible limit in the majority of the study area (Fig. 3(a, b)). On the contrary to $\mathrm{Ca}^{2+}$ and $\mathrm{Mg}^{2+}, \mathrm{Na}^{+}$and $\mathrm{K}^{+}$exhibit positive trends from the escarpment to the rift floor (Fig 3 (c, d)). The $\mathrm{Na}^{+}$content ranged between 2.3 to $858 \mathrm{mg} / \mathrm{l}$ with an average value of $133.6 \mathrm{mg} / \mathrm{l}$. $\mathrm{Na}^{+}$is the dominant cation, but highly variable as characterized by the standard deviation being larger than the mean value (Table 4). Twenty-five percent of the groundwater samples had high level of $\mathrm{Na}^{+}$crossing the tolerable limit in drinking water (>200 mg/l). Similarly, the $\mathrm{K}^{+}$content varied between 0.66 and $152 \mathrm{mg} / \mathrm{l}$ with an average value of 16.7 $\mathrm{mg} / \mathrm{l}$. According to WHO (2011), $42 \%$ of the groundwater samples exceed the allowable limit (12 $\mathrm{mg} / \mathrm{l})$. These groundwater samples exceeding the allowable limit for $\mathrm{Na}^{+}$and $\mathrm{K}^{+}$are located in the rift floor (Fig. 3(c, d)), suggesting that the groundwater in elevated (>2000 $\mathrm{m}$ a.s.l.) regions satisfies the WHO guideline and is suitable for drinking purposes.

Anions dominances of the groundwater were observed as $\mathrm{HCO}_{3}{ }^{-}>\mathrm{Cl}^{-}>\mathrm{SO}_{4}{ }^{2-}>\mathrm{NO}_{3}{ }^{-}$(Table 1; Fig 3(e-h)). The $\mathrm{HCO}_{3}{ }^{-}$ content varied from 43.6 to $2,547 \mathrm{mg} / \mathrm{l}$ with an average value of $433 \mathrm{mg} / \mathrm{l}$. Bicarbonate is the dominant anion characterized by an increasing trend from the escarpment towards the rift floor, which corresponds to the increase in $\mathrm{Na}^{+}$and $\mathrm{K}^{+}$. In the majority of the study area (85.5\% of the samples), the $\mathrm{HCO}_{3}{ }^{-}$values exceed the desirable limit of $120 \mathrm{mg} / \mathrm{l}$ set by WHO (2011). As there is no source rock in the study area, the $\mathrm{Cl}^{-}$and $\mathrm{SO}_{4}{ }^{2-}$ content is quite low and below the WHO (2011) guideline value of $250 \mathrm{mg} / \mathrm{l}$ (Table 1; Fig 3 (f, g)). In the study area, the content of $\mathrm{NO}_{3}{ }^{-}$varied from bdl to $41.1 \mathrm{mg} / \mathrm{l}$ with an average value $25.3 \mathrm{mg} / \mathrm{l}$. The relatively higher content of $\mathrm{NO}_{3}{ }^{-}$in the rift floor is associated with agricultural and other anthropogenic activities that contribute to the contamination of groundwater. However, the concentration of $\mathrm{NO}_{3}{ }^{-}$in all water samples is below the permissible limit (WHO 2011) of $50 \mathrm{mg} / \mathrm{l}$ throughout the basin (Fig. 3 (h)).

In the studied region, the concentrations of $\mathrm{F}^{-}$ranged from bdl to $40 \mathrm{mg} / \mathrm{l}$, with a mean of $3.4 \mathrm{mg} / \mathrm{l}$ (Table 1 ). It has been found that 24 (44\%) out of 55 water samples had $\mathrm{F}^{-}$above the allowable limit (1.5 mg/l) (Table 1). Though $\mathrm{F}^{-}$at optimum concentration is beneficial for the human body (Brunt et al. 2004; Mjengera, and Mkongo 2003; Firempong et al. 2013), drinking water with $\mathrm{F}^{-}$levels greater than $1.5 \mathrm{mg} / \mathrm{l}$ causes adverse human health effects (Feenstra et al. 2007; Peter 2009). High $\mathrm{F}^{-}$concentration is one of the major water quality problems affecting people residing in ERV including the study area (Tekle-Haimanot et al. 1987; Gizaw 1996; Kloos and Tekle-Haimanot 1999; Reimann et al. 2003; Rango et al. 2009; Mesele and Mechal 2020).

Possible site for Fig. $3(a-h)$

Fig. 4 portrays the spatial distribution of the $\mathrm{F}^{-}$concentration in groundwater across the basin showing a general increase from both Western and Eastern escarpment towards the rift floor. The escarpment shows low $\mathrm{F}^{-}$concentration 
satisfying the WHO water quality standard $(<1.5 \mathrm{mg} / \mathrm{l})$. This suggests that the escarpment groundwaters are a safe source of water for drinking use. On the contrary, all the fluoride-rich groundwater in the study area crossing the threshold value is found in the rift floor. In the rift floor, $\mathrm{F}^{-}$is a major water quality degrader, especially for those communities living west and south of Lake Ziway, where $\mathrm{F}^{-}$reaches $40 \mathrm{mg} / \mathrm{l}$ (Fig. 4). Millions of people have been forced to use these water sources for prolonged period and as a result both dental and skeletal fluorosis are very common in the area (Rango et al. 2020).

\section{Possible site for Fig. 4}

\subsubsection{Hydrochemical facies and controlling processes}

The hydrochemical facies of groundwater in ZLB were identified by plotting the concentrations of major ions in the piper plot (Piper 1964; Fig. 5). Three distinct hydrochemical facies $\left(\mathrm{Ca} / \mathrm{Mg}-\mathrm{HCO}_{3}, \mathrm{Na} / \mathrm{Ca}-\mathrm{HCO}_{3}\right.$, and $\left.\mathrm{Na}-\mathrm{HCO}_{3}\right)$ were identified across the study area. The headwater of ZLB, Western and Eastern escarpments, show a weakly mineralized $\mathrm{Ca} / \mathrm{Mg}-\mathrm{HCO}_{3}$ hydrochemical facies. On the other hand, rift floor groundwater including thermal groundwater exhibits a highly mineralized $\mathrm{Na}-\mathrm{HCO}_{3}$ hydrochemical facies with $\mathrm{Na}^{+}$and $\mathrm{HCO}_{3}{ }^{-}$strong dominance over the other ionic species. $\mathrm{Na} / \mathrm{Ca}-\mathrm{HCO}_{3}$ hydrochemical facies were the mixture of the two extreme hydrochemical facies occupying the transition zone and shallow groundwater in the rift floor. In summary, groundwater systematically evolves from a $\mathrm{Ca} / \mathrm{Mg}-\mathrm{HCO}_{3}$ to $\mathrm{Ca} / \mathrm{Na}-\mathrm{HCO}_{3}$ and lastly to $\mathrm{Na}-\mathrm{HCO}_{3}$ hydrochemical facies along the groundwater flow direction from the escarpments to the center of the rift floor.

\section{Possible site for Fig. 5}

Different hydrochemical processes can be involved during the hydrochemical evolution of groundwater along the groundwater flow path across the study area. To identify the major hydrochemical processes responsible for the evolution, the most widely used Gibbs diagram (Gibbs 1970) was constructed. As shown in Fig. 6, almost all groundwater samples fall in the rock-water interaction zone suggesting weathering of rock-forming minerals as the origin of the dissolved ions.

\section{Possible site for Fig.6}

Among different water-rock interactions in silicate-dominated lithological classes, silicate weathering is one of the major hydrochemical processes governing groundwater chemistry (Garrels and Mackenzie 1967; Freeze and Cherry 1979). According to Rajmohan and Elango (2004) and Kumar et al. (2006), the importance of silicate weathering can be recognized by studying the scatter plots of total cations $\left(\mathrm{TZ}^{+}\right)$versus $\left(\mathrm{Ca}^{2+}+\mathrm{Mg}^{2+}\right)$ and $\left(\mathrm{Na}^{+}+\mathrm{K}^{+}\right)$. As illustrated in Fig. 7(a), all escarpments and some rift floor groundwater samples linearly spread between 1:2 and 1:1 lines suggesting $\mathrm{Ca}^{2+}$ and $\mathrm{Mg}^{2+}$ have originated from the weathering of basaltic aquifers. Likewise, the plot of $\mathrm{TZ}^{+}$and $\left(\mathrm{Na}^{+}\right.$ $+\mathrm{K}^{+}$) shows the majority of the groundwater samples are plotted above the 1:1 line indicating acidic rock weathering is the key hydrochemical processes which adds $\mathrm{Na}^{+}$and $\mathrm{K}^{+}$to the groundwater. From these results, it can be inferred that silicate weathering is the prime sources of $\mathrm{Na}^{+}, \mathrm{Ca}^{2+}, \mathrm{Mg}^{2+}, \mathrm{K}^{+}$and the balancing $\mathrm{HCO}_{3}{ }^{-}$into the groundwater in the study area. The exceptionally high $\mathrm{Na}^{+}$and $\mathrm{HCO}_{3}{ }^{-}$content in some of rift floor and thermal groundwater samples 
is probably related to silicate weathering aided by the uptake of mantle $\mathrm{CO}_{2}$ leaking through deep-seated faults in addition to the ordinary soil $\mathrm{CO}_{2}$ (Darling et al. 1996; Gizaw 1996; Mechal et al. 2017).

\section{Possible site for Fig.7}

The dominance of $\mathrm{Na}-\mathrm{HCO}_{3}$ hydrochemical facies in the rift floor aquifers, cannot only be explained by silicate weathering. Besides silicate weathering, cation exchange might have an effect on groundwater chemistry as observed in similar geological setting ( $\mathrm{Li}$ et al. 2013; Wu and Sun 2016). To assess the involvement of cation exchange reactions in ZLB, the two Chloro-Alkaline Indices (CAIs), CAI - I and CAI - II were applied as recommended by Schoeller (1965) These two indices are expressed as Equations (5) and (6) (the concentration of the ions are expressed in meq/l).

$\mathrm{CAI}-\mathrm{I}=\mathrm{Cl}^{-}-(\mathrm{Na}+\mathrm{K}) / \mathrm{Cl}$

$\mathrm{CAI}-\mathrm{II}=\mathrm{Cl}^{-}-(\mathrm{Na}+\mathrm{K}) /\left(\mathrm{SO}_{4}{ }^{2-}+\mathrm{HCO}_{3}{ }^{-}+\mathrm{CO}_{3}{ }^{2-}+\mathrm{NO}_{3}{ }^{-}\right)$

When there is an exchange between $\mathrm{Na}^{+}$in groundwater with $\mathrm{Ca}^{2+} / \mathrm{Mg}^{2+}$ of the aquifer material, both indices CAI - I and II will be positive. Conversely, the negative CIAs values indicate a reverse ion exchange. Accordingly, the calculated CAI - I and CAI - 2 values are negative for all groundwater samples with an average value of -13.54 and -0.57 , respectively. Thus, $\mathrm{Ca}^{2+} / \mathrm{Mg}^{2+}$ in groundwater exchanging with $\mathrm{Na}^{+}$in aquifer forming rocks and sediments leading to the further increment $\mathrm{Na}^{+}$with parallel depletion of $\mathrm{Ca}^{2+} / \mathrm{Mg}^{2+}$ in the groundwater along the flow path. The hydrochemical evidence suggests that silicate weathering and cation exchange played a role for the evolution of the groundwater from the low mineralized $\mathrm{Ca} / \mathrm{Mg}-\mathrm{HCO}_{3}$ to high mineralized $\mathrm{Na}-\mathrm{HCO}_{3}$ hydrochemical facies along groundwater flow.

As suggested by several authors (Gizaw 1996; Yirgu et al. 1999; Rango et al. 2009; Haji et al. 2018; Bianchini et al. 2020), the above-mentioned process, silicate weathering and cation exchange, are also responsible for the high content of $\mathrm{F}^{-}$exceeding the permissible limit in the rift sector of the study area (Fig.4). Fluoride is positively correlated with $\mathrm{Na}^{+}\left(R^{2}=0.83\right), \mathrm{HCO}_{3}{ }^{-}\left(R^{2}=0.65\right)$, TDS $\left(R^{2}=0.65\right)$ and negatively correlated with $\mathrm{Mg}^{2+}\left(\mathrm{R}^{2}=-0.18\right)$ and $\mathrm{Ca}^{2+}\left(\mathrm{R}^{2}=\right.$ -0.3). These relationships suggest that silicate weathering gradually releases $\mathrm{F}^{-}$into groundwater reservoir as it flows from the bordering escarpments to the rift axis. Simultaneously, cation exchange is also believed to remove $\mathrm{Ca}^{2+}$ from the groundwater to replace $\mathrm{Na}^{+}$in aquifer material. This results freely circulating $\mathrm{F}^{-}$in the rift center as there is not sufficient $\mathrm{Ca}^{2+}$ to precipitate as $\mathrm{CaF}_{2}$ (Rango et al. 2010; Haji et al. 2018; Bianchini et al. 2020).

As stated by Keshavarzi et al. (2010), in acidic water, $\mathrm{F}^{-}$is adsorbed on a clay surface, while in alkaline water, $\mathrm{F}^{-}$is desorbed from solid phases; therefore, alkaline $\mathrm{pH}$ is more favorable for $\mathrm{F}^{-}$dissolution. In the present study, the gradual change in $\mathrm{pH}$ from the slightly acidic nature in the upstream to sub-alkaline water in the rift floor is highly favored the dissolution of $\mathrm{F}^{-}$which is reflected by positive correlation with $\mathrm{pH}\left(\mathrm{Fig} 8 ; \mathrm{R}^{2}=0.42\right.$ ). The influence of alkalinity on $\mathrm{F}^{-}$dissolution is also recognized by several other authors (e.g., Saxena and Ahmed 2003; Jacks et al. 2005; Rafique et al. 2009; Haji et al. 2018).

\section{Possible site for Fig.8}




\subsubsection{Trace element distribution in the groundwater}

According to Gaillardet et al. (2003), trace elements are known by their concentrations lower than $1 \mathrm{mg} / \mathrm{l}$ in groundwater. Despite their low concentrations, the level of their presence plays either negative or positive role in human health (WHO, 2011). To identify potentially toxic trace elements, the concentrations of trace elements in the groundwater samples were compared with existing drinking water quality guidelines (WHO 2011; US EPA 2003).

Apart from $\mathrm{Be}$ and $\mathrm{Bi}$, the analyzed trace elements (Mn, As, U, Mo, Pb, Cr, Sr, Li, Sc, Ti, V, Co, Ni, Cu, Zn, Ga, Rb, $\mathrm{Cd}, \mathrm{Sb}$, and $\mathrm{Ba}$ ) were detected in the majority $(75 \%)$ of the collected samples in the ZLB. The low content of Be and Bi below the detection limit might be linked to the lower concentrations in aquifer materials (volcanic rocks). For most of trace elements ( $\mathrm{Sr}, \mathrm{Li}, \mathrm{Sc}, \mathrm{Ti}, \mathrm{V}, \mathrm{Co}, \mathrm{Ni}, \mathrm{Cu}, \mathrm{Zn}, \mathrm{Ga}, \mathrm{Rb}, \mathrm{Cd}, \mathrm{Sb}$, and $\mathrm{Ba}$ ) reported in Table 4, the measured concentrations were far below the guideline values and are not expected to cause harm to people. However, a few potentially toxic trace elements such as Mn, As, U, Pb, and Mo were above the permissible limit (WHO 2011).

The concentration of these toxic trace elements in the groundwater were non-uniform across the watershed ranging from bdl to high values exceeding the health-based value for drinking water (Table 4). Manganese is an important element for human, but can cause adverse health effects due to over or insufficient consumption. Concentrations below $40 \mu \mathrm{g} / \mathrm{l}$ are usually acceptable to consumers (WHO 2011). According to Erikson and Aschner (2003) and Vartanian et al. (1999), over consumption of Mn beyond the acceptable limit may result to infertility, malfunction of the immune system and Parkinson-like symptoms. Manganese concentration in the ZLB ranges from bdl to $466 \mu \mathrm{g} / \mathrm{l}$ with mean value of $37.6 \mu \mathrm{g} / \mathrm{l}$. Manganese level is quite low in the western and eastern escarpments but the central rift floor is highly enriched rising to 10 times higher than the permissible limit (Fig.9a). The concentration of Mn in this study is higher than those reported in Tertiary sedimentary sandstone aquifer in Nigeria (180 $\mu \mathrm{g} / \mathrm{l}$; Oyem et al. 2015) and Mississippi River Valley alluvial, sandstone and glacial aquifers in USA (300 $\mu \mathrm{g} / 1$; McMahon et al. 2019) but significantly lower than Nubian sandstone aquifer in Egypt (36, $340 \mu \mathrm{g} / \mathrm{l}$; Khozyem et al. 2019) and Carboniferous and Devonian sedimentary aquifer in Scotland (1900 $\mu \mathrm{g} / \mathrm{l}$; Homoncik et. 2010).

Arsenic is tasteless, odorless, and colorless but has been proven to be toxic at very low concentrations, even below the recommended level of $10 \mu \mathrm{g} / \mathrm{l}$ (WHO 2011). Numerous epidemiological studies (e.g., Smith et al. 1998; Parvez et al. 2008; Tchounwou et al. 2018) documented that drinking As contaminated water can cause skin, liver, lung, kidney and bladder cancer. Arsenic in the groundwater samples ranged from bdl to $278 \mu \mathrm{g} / \mathrm{l}$, with a mean of $30.2 \mu \mathrm{g} / \mathrm{l}$. Arsenic shows strong correlation $\left(\mathrm{R}^{2}>0.8\right)$ with $\mathrm{EC}, \mathrm{Na}^{+}, \mathrm{K}^{+}, \mathrm{HCO}_{3}{ }^{-}$, and $\mathrm{F}^{-}$Negatively associated with $\mathrm{Mg}\left(\mathrm{R}^{2}=-0.27\right), \mathrm{Ca}^{2+}$ $\left(\mathrm{R}^{2}=-0.31\right)$ and almost no distinctive association with $\mathrm{NO}_{3}\left(\mathrm{R}^{2}=-0.07\right)$. These relationships suggest that As contamination in the study area is geo-genic and tied with Quaternary sediments and rhyolitic volcanic rocks instead of basic rocks (e.g., basalts) (Barringer and Reilly 2013). This finding is in agreement with Rango et al. (2010, 2013) and Bianchini et al. (2020). The spatial distribution of As concentrations in the groundwater (Fig. 9b) shows that areas to the west and south of lake Ziway that represents zone of high As concentrations (As $>10 \mu \mathrm{g} / \mathrm{l}$ ). Arsenic levels were much lower and far below the permissible limit in the Western and Eastern escarpments of the study area. Some studies (e.g., Reimann et al. 2003; Rango et al. 2010, 2013) reported the occurrence of As contamination in the MER accompanied by high F content. The As content is more pronounced mainly in hot springs (up to $1019 \mu \mathrm{g} / \mathrm{l}$ ) in the 
southern MER (Bianchin et al. 2020). It should also be noted that the content of As in the Quaternary sediments and rhyolitic volcanic aquifers of the study area is much higher than those of limestone aquifer in Nigeria $(160 \mu \mathrm{g} / \mathrm{l}$; Gbadebo 2005); alluvial aquifer in India (68 $\mu \mathrm{g} / \mathrm{l}$; Yadav et al. 2020) and lower than crystalline basement aquifers in

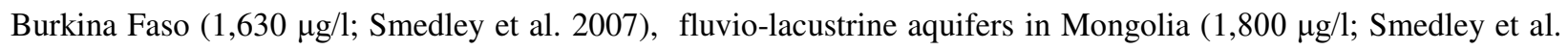
2003) and marine and fluvial origin alluvial sediment aquifer in Vietnam and Cambodia (1,340 $\mu \mathrm{g} / \mathrm{l}$; Buschmannet al. 2008).

According to Milvy and Cothern (1990) and Brugge and Buchner (2011), Uranium is considered to be non-essential element for human health and the exposure to extremely low concentration in groundwater results potential problem in kidney and bones. Uranium concentrations ranged between bdl and $43.9 \mu \mathrm{g} / \mathrm{l}$ with a mean of $4.73 \mu \mathrm{g} / \mathrm{l}$. Uranium level was generally very low in the study area but anomalous concentration exceeding the WHO (2011) threshold value $(15 \mu \mathrm{g} / \mathrm{l})$ is observed to the west of lake Ziway (Fig.1). These zones also overlap with high F >1.5 mg/l, As >10 $\mu \mathrm{g} / \mathrm{l}$ and $\mathrm{Mn}>40 \mu \mathrm{g} / \mathrm{l}$. The range of $\mathrm{U}$ concentrations observed in this study area falls within the range found in Ethiopian Rift (Reimann et al. 2003; Rango et al. 2013). However, U concentrations observed in this study were found to be lower than observed in granites and pegmatites in Sweden $(470 \mu \mathrm{g} / 1$; Selden et al. 2009) and Quaternary sediments in China (288 $\mu \mathrm{g} / \mathrm{l}$; Wu et al. 2014) but higher than alluvial sediments in Bangladesh (10 $\mu \mathrm{g} / \mathrm{l}$; Frisbie et al. 2009) and Vietnam (5.1 $\mu \mathrm{g} / 1$; Buschmann et al. 2008).

Lead content in groundwater obtained from this study ranged from bdl to $71.7 \mu \mathrm{g} / \mathrm{l}$ with a mean value of $4.1 \mu \mathrm{g} / \mathrm{l}$. Only five percent of the water samples collected throughout the study area exceeded the WHO (2011) recommended limit of $10 \mu \mathrm{g} / \mathrm{l}$. Several authors (e.g., Cunningham and Saigo1997; Baykov et al.1996; Jaishankar et al. 2014) have shown that frequent over intake of $\mathrm{Pb}$ can initiate tiredness, hypertension, anemia behavioral changes, irritability and impairment of intellectual functions. Molybdenum is an indispensable trace element for human health; nonetheless, over doses can be harmful (Pauline and Kinniburgh 2017). Similarly, Molybdenum concentrations ranged from bdl to $104 \mu \mathrm{g} / \mathrm{l}$ with a mean value of $6.2 \mu \mathrm{g} / \mathrm{l}$. Molybdenum concentration was generally very low in ZLB and only five percent of the groundwater samples, located in the rift floor to the west of Lake Ziway, had high concentrations exceeding the WHO (2011) recommended value for drinking water $(70 \mu \mathrm{g} / \mathrm{l})$. Molybdenum has good association with As $\left(R^{2}=0.53\right), P b\left(R^{2}=0.21\right)$ and $U\left(R^{2}=0.71\right)$ suggesting that the reactive Quaternary sediments and rhyolitic volcanic rocks are also the potential source in the groundwater triggered by high geothermal activity in the area. (Fig.1).

Multiple violations of trace elements ( $\mathrm{Mn}, \mathrm{As}, \mathrm{U}, \mathrm{Pb}$, and $\mathrm{Mo}$ ) is very common concurrently in the groundwater samples in the rift floor section of ZLB. This simultaneous occurrence of toxic elements could pose further threat to human health through their mixture products (Bopp et al. 2018; Kortenkamp and Faust 2018). A mixture risk assessment is not considered in this work; however, the result suggests that groundwater of the study area possibly cause health concerns for the people consuming directly without any treatment from the groundwater sources.

\section{Possible site for Fig. 9}




\subsection{Assessment of groundwater for irrigation}

Water quality, soil types, and agricultural practices are essential factors for successful performance of irrigation. However, water quality can have a profound role in crop productivity as well as soil fertility. Therefore, evaluating the suitability of groundwater for irrigation purpose is vital for proper growth of crops and soil fertility. The most widely applied irrigation water quality indicator that can potentially show the quality of groundwater for irrigation purpose are EC, SAR, Na\%, RSC, and PI. These indices were calculated by the relation provided in Table 3 and groundwater samples were classified according to its irrigation usage (Table 5).

\section{Possible site for Table 5}

\subsubsection{Sodium Adsorption Ratio (SAR) and USSL diagram}

Sodium Adsorption Ratio is used to measure the relative proportion of $\mathrm{Na}^{+}$concentration to those of $\mathrm{Ca}^{2+}$ and $\mathrm{Mg}^{2+}$ in a water sample. The excessive $\mathrm{Na}^{+}$concentration relative to $\mathrm{Ca}^{2+}$ and $\mathrm{Mg}^{2+}$ reduces soil hydraulic conductivity and consequently hinders the supply of water required for plant growth. The excess $\mathrm{Na}^{+}$or limited $\mathrm{Ca}^{2+}$ and $\mathrm{Mg}^{2+}$ content is determined by SAR value and can be evaluated using standard equation provided in Table 3 (Richards 1954).

The SAR values of the groundwater in the ZLB ranged from 0.13 to $237.4 \mathrm{meq} / \mathrm{l}$ with mean value of $3.4 \mathrm{meq} / 1$ (Table 5). The SAR value of the groundwater displays a positive trend towards the rift floor. The increase in SAR value from the escarpment towards the rift center is linked to strong silicate hydrolysis aided by high geothermal gradient. Based on SAR values, more than $80 \%$ of the groundwater samples fall in Excellent category and would be suitable for irrigation. The remaining 20\% water samples classified as Doubtful to Unstable range and are mainly situated in the rift floor.

In addition to absolute SAR, the suitability of the groundwater for irrigation was also appraised based on US Salinity Laboratory (USSL) plot (Richards 1954), in which the EC is considered as salinity hazard while SAR as alkalinity hazard (Fig. 11a). The plot shows that 14 of the groundwater samples mainly belonging to the escarpments fall in the class $\mathrm{C}_{1}-\mathrm{S}_{1}$ with low salinity and alkalinity $/ \mathrm{Na}^{+}$which are suitable for irrigation usage in almost all soil types. Twentysix groundwater samples lie in the class $\mathrm{C}_{2}-\mathrm{S}_{1}$ and $\mathrm{C}_{3}-\mathrm{S}_{1}$ (medium to high salinity and low $\mathrm{Na}^{+}$). These waters can be utilized for irrigation application in almost all soil types with slight danger of exchangeable $\mathrm{Na}^{+}$. Most of the thermal and rift floor groundwater were classified in high to very high salinity water $\left(\mathrm{C}_{3}\right.$ and $\left.\mathrm{C}_{4}\right)$ and high to very high $\mathrm{Na}^{+}\left(\mathrm{S}_{3}\right.$ and $\mathrm{S}_{4}$ ) field and thus cannot be applied in soils with limited drainage. Even with sufficient drainage, special management for salinity control is needed and crops with good salt tolerance should be preferred. In general, groundwater from the escarpments of the basin were suitable for irrigation usage with minor impact to the soil and crops. On the other hand, the western lake margin areas categorized as poor-quality water and requires treatment before irrigation application.

\section{Possible site for Fig. 10}

\subsubsection{Percent sodium (\% $\mathrm{Na}$ ) and Wilcox diagram}

Percent sodium is also utilized in evaluation of groundwater suitability for irrigation usage, as the concentration of $\mathrm{Na}^{+}$reacts with soil to lower its permeability (Todd 1980). When the content of $\mathrm{Na}^{+}$is high in irrigation water, $\mathrm{Na}^{+}$ 
tend to be absorbed by clay particles discharging $\mathrm{Ca}^{2+}$ and $\mathrm{Mg}^{2+}$ ions. This exchange process of $\mathrm{Na}^{+}$in water for $\mathrm{Ca}^{2+}$ and $\mathrm{Mg}^{2+}$ in soil lowers the permeability and ultimately results in soil with low infiltration rate. As a result, air and water circulation is inhibited during wet situations, and such soils become typically hard when dry (Saleh et al. 1999).

The computed \% Na for the ZLB ranged from 11.7 to $99.9 \%$ with mean value of $56.2 \%$ (Table 5). The Wilcox (1955) plot (Fig. 10b) relating \% Na and EC illustrates that 38 (70\%) groundwater samples belong to Excellent to Permissible, 4 (7\%) to Permissible to Doubtful, 6 (11\%) to Doubtful to Unsuitable, and 7 (13\%) to Unsuitable categories.

\subsubsection{Residual sodium carbonate (RSC)}

The other limiting factor for irrigation water is the excess of $\mathrm{CO}_{3}{ }^{-}$and $\mathrm{HCO}_{3}{ }^{-}$concentrations with regards to $\mathrm{Ca}^{+2}$ and $\mathrm{Mg}^{+2}$ which can deteriorate the irrigation water quality as it results the precipitation of the alkali metals mainly $\mathrm{Ca}^{+2}$ and $\mathrm{Mg}^{+2}$. The precipitation of $\mathrm{Ca}^{2+}$ and $\mathrm{Mg}^{+2}$ as carbonate minerals may amplify the $\mathrm{Na}^{+}$concentration and consequently increase SAR values (Eaton 1950). Based on RSC value groundwater can be categorized Suitable (RSC< $1.5 \mathrm{meq} / \mathrm{l})$, Unsuitable (RSC>2.5 meq/l), and Marginally suitable (1.25-2.5 meq/l) for irrigation (Table 5) (Deshpande and Aher 2012).

According to RSC values, $38 \%$ of the water samples are Suitable for irrigation application, and about $18 \%$ of the water fall under Marginally suitable category and the remaining $44 \%$ of water samples are lie in Unsuitable category. More than $50 \%$ of the water samples found to be fairly Suitable for irrigation and are identified in the escarpments part of the basin. On the contrary, the Unsuitable water samples are mainly located in southeastern and central part of the basin. High RSC potentially can have damaging effect to the physical properties of soil as it induces dissolution of organic matter and finally generate a black stain on the soil surface when it dries (Kumar et al. 2007; Srinivasamoorthy et al. 2014).

\subsubsection{Permeability Index (PI)}

The Permeability Index is one of the important irrigation water quality indicators, as the soil permeability is affected by continues application of irrigation water, which is controlled by the $\mathrm{Na}^{+}, \mathrm{Ca}^{2+} \mathrm{Mg}^{2+}$, and $\mathrm{HCO}_{3}{ }^{-}$contents of the soil. Doneen (1964) developed a criterion for evaluating the suitability of water for irrigation usage based on PI and waters can be categorized as classes Excellent (>75\%), Good (25-75\%), and Doubtful (<25\%) (Table 5).

In the ZLB, the computed PI values of the groundwater varied between 39.9 and 136.4 meq/l, with mean value of $100.5 \mathrm{meq} / \mathrm{l}$. Based on PI value, the greater proportion of the water samples (98\%) clustered under Excellent to Good classes and are generally suitable for irrigation.

\subsection{Water Quality Index}

\section{3 .1 Drinking Water Quality Index (DWQI)}

DWQI was applied to get an overall picture of groundwater quality for drinking purpose in the LZB. The computed DWQI values are then used to categorize the groundwater in to five classes as Excellent, Good, Poor, Very Poor, and Unsuitable (Table 6) for drinking use (Sahu and Sikdar 2008). 
The calculated DWQI values of the groundwater in the basin range between 2.7 to 714 with an average of 94 . Of the 55 groundwater samples, $56 \%$ of the samples belonged to Excellent and $20 \%$ to Good and are considered to be suitable for drinking purpose. However, the remaining $24 \%$ categorized as Poor to Unsuitable ranges (Table 6) and cannot be directly utilized for human consumption without proper treatment.

\section{Possible site for Table 6}

DWQI spatial distribution map (Fig.11a) was created based on the calculated DWQI values. It can easily be observed that DWQI values varied from 12.7 Excellent class to 714 Unsuitable class for drinking purposes and systematically increases from the escarpments towards the rift axis. Lower DWQI values below 100 are observed in the upper escarpments indicating that suitable for drinking purposes. The low value in the escarpments is associated to the fast groundwater replenishment and low rock-water interaction rate due to short travel time. As a result, the concentration of highest influencing parameters (see Table 2) of DWQI usually found to be below the drinking water guideline.

On the other hand, high DWQI values above 100 designated as Poor to Unsuitable water quality status was observed in the rift floor. As discussed in the section 4.1.2, silicate hydrolysis and cation exchange processes along the groundwater flow direction from the escarpments towards the rift floor through acidic volcanic rocks enriching the groundwater in $\mathrm{F}^{-}, \mathrm{Na}^{+}, \mathrm{K}^{+}$, and $\mathrm{HCO}_{3}{ }^{-}$with a corresponding increment of $\mathrm{pH}$ and EC. As a result, almost all influencing parameters of DWQI were found to be in excess and went above the permissible limit, which led to high DWQI value. The exceptional very high DWQI values to the west of Lake Ziway is mainly related to co-existence of the elevated concentration of toxic elements in Quaternary sediment and rhyolitic volcanic rock aquifer such as F, $\mathrm{Mn}, \mathrm{As}, \mathrm{U}, \mathrm{Pb}$, and Mo. From Fig.4 and 9, it can be inferred that the areas that have high F, Mn, and As concentration also have high DWQI values. This substantiates the validity of DWQI map. In general, the poor drinking water quality in ZLB is associated with the combined action of silicate hydrolysis and cation exchange as well the occurrence of very reactive litho-type.

\subsubsection{Irrigation Water Quality Index (IWQI)}

Suitability of groundwater for irrigation purpose can be assessed either taking into consideration of the chemical parameters (indices) (e.g., Li et al. 2013; Kawo and Karuppannan 2018) or combination of many indices (e.g., Meireles et al. 2010; RamyaPriya and Elango 2018). Rating of water for irrigation purpose using individual chemical parameters can be helpful; however, the overall suitability based on many influencing parameters provide concise information for decision by managers and administrative organizations. The calculated IWQI values of the groundwater in the basin ranged from 13.2 to 520 with an average of 106. In groundwater, $28 \%$ of the samples belonged to Excellent, $46 \%$ to Good, $15 \%$ to Poor, $7 \%$ to Very poor, and $4 \%$ to Unsuitable category (Table 6).

The spatial variation of IWQI values in the ZLB is shown in Fig.11 (b). Like the DWQI map, groundwater quality is generally characterized by an Excellent water quality for irrigation in the headwater regions of the ZLB and progressively become Unsuitable for irrigation water uses in the rift floor. In the rift floor, the parameters considered for the IWQI are characterized by high EC, SAR, Na\%, RSC and PI values leading to high IWQI values. This is 
directly associated to the gradual evolution of groundwater from low mineralized $\mathrm{Ca} / \mathrm{Mg}-\mathrm{HCO}_{3}$ type in the escarpment to strongly mineralized $\mathrm{Na}-\mathrm{HCO}_{3}{ }^{-}$type in the rift floor.

\section{Possible site for Fig. 11}

\section{Conclusion}

Water quality is one of the most important factors for sustainable development in the ERV, which is characterized by arid and semi-arid climate and serious water shortage often associated with water quality problems. In this study, the suitability of groundwater for drinking and irrigation use was evaluated in LZB of the ERV. Water quality of 55 groundwater samples were assessed for major and trace elements concentrations. Results showed that groundwater samples from the escarpments are typically characterized by low TDS and $\mathrm{Ca} / \mathrm{Mg}-\mathrm{HCO}_{3}$ hydrochemical facies. The subsequent interaction of these waters with the acidic volcanic rocks along the flow path towards the rift axis prompts a general increase of TDS and evolution of hydrochemical facies towards $\mathrm{Na}-\mathrm{HCO}_{3}$. Comparison of major and trace element concentrations of the water samples with drinking guidelines (WHO 2011) indicated that large percentages (for $\mathrm{Na}, \mathrm{K}, \mathrm{F}$ and $\mathrm{HCO}_{3}$ ), and small percentages (for $\mathrm{Mn}, \mathrm{As}, \mathrm{U}, \mathrm{Pb}$ and $\mathrm{Mo}$ ) of samples are found exceeding the permissible limits. Water rock interactions such as silicate weathering and ion exchange are the prime processes controlling groundwater quality with limited anthropogenic stress.

The overall groundwater quality for drinking purpose, DWQI values, show strong spatial variation in the ZLB ranging from 12.7 (Excellent class) to 714 (Unsuitable class) with an average of 94. DWQI suggests that groundwater quality is generally characterized by an Excellent water quality for drinking water use in the head water regions of the ZLB and progressively become Unsuitable in the rift floor. The poor groundwater quality in the downstream section of the basin is associated with an increase in TDS coupled with the co-occurrence and accumulation of multiple toxic trace elements ( $\mathrm{F}, \mathrm{Mn}, \mathrm{As}, \mathrm{U}, \mathrm{Pb}$ and $\mathrm{Mo}$ ) along groundwater flow. For the community residing in areas with very high DWQI values, especially to the west of Lake Ziway where major cities are located, it is necessary to look for alternative sources of water or device new methodologies that can remove multi-toxic elements from the groundwater.

The spatial assessment of irrigation water quality inferred from water quality indicators such as IWQI, EC, SAR, $\mathrm{Na} \%$, RSC and PI values showed the existence of different water quality class across the study area. The significant proportion of rift floor groundwaters samples fall in moderately Suitable to Unsuitable classes for irrigation use. These classes of groundwater might destruct the physical properties soils (e.g., soil drainage) and lower crop productivity in the area. The occurrence of such irrigation water quality in this region is mainly attributed to the dominance of $\mathrm{Na}$ and $\mathrm{HCO}_{3}$ arising from the late stage evolution of the groundwater. On the contrary, the escarpment groundwaters fall in the Suitable category in any of the above irrigation water quality indicators.

The spatial assessment of groundwater quality has led to a better understanding of water quality degraders and overall water quality status of ZLB. DWQI and IWQI maps have provided integrated information about the suitability of the groundwater for different purposes, which helps policy makers and managers to identify developed water schemes falling in unsuitable areas and thus to take appropriate measures and identify new areas for future groundwater resource development. 


\section{Acknowledgments}

The Authors would like to acknowledge Adama Science and Technology University (ANSD/02/1252/09), for

financial support to conduct this research. The authors also acknowledge Muhammed Haji for support with liquid analyses. 
Date: December 14, 2020

\title{
Conflict of interest statement
}

\section{Manuscript title: Application of multi hydrochemical indices for spatial groundwater quality assessment: Ziway Lake Basin of the Ethiopian Rift Valley}

The authors whose names are listed immediately below confirm that we have NO affiliations with or involvement in any organization or entity with any financial interest or non-financial interest in the subject matter or materials discussed in this manuscript.

Authors

Abraham Mechal

Hassen Shube

Tewodros Rango Godebo

Kristine Walraevens

Steffen Birk

Kind regards,

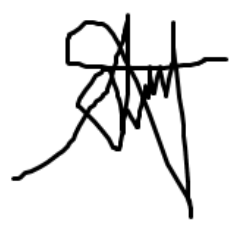

\author{
Abraham Mechal (PhD) \\ Assistant Professor of Hydrogeology \\ Associate Dean for Mineral Exploration, Extraction and processing Center of Excellence \\ Department of Geology/Addis Ababa Science and Technology University \\ Mobile: +251-911890871 \\ E-mail: abrichyd2011@gmail.com/abraham.mechal@aastu.edu.et \\ Web: www.aastu.edu.et
}




\section{References}

Abbasnia A, Yousefi N, Hossein AM, Nabizadeh R, Radfard M, Yousefi M, Alimohammadi M (2018) Evaluation of groundwater quality using water quality index and its suitability for assessing water for drinking and irrigation purposes: Case study of Sistan and Baluchistan province (Iran). Human and ecological risk assessment, vol. 0, no. 0, 1-19 doi.org/10.1080/10807039.2018.1458596.

Abbasi T, Abbasi SA (2012) Water quality indices. Burlington: Elsevier Science.

Amangabara GT, Ejenma E (2012) Groundwater quality assessment of Yenagoa and environs Bayelsa State, Nigeria between 2010 and 2011. Resour. Environ. 2 (2), 20-29.

Amiri V, Nakhaei M, Lak R, Kholghi, M (2016) Assessment of seasonal groundwater quality and potential saltwater intrusion: A study case in Urmia coastal aquifer (NW Iran) using the groundwater quality index (GQI) and hydrochemical facies evolution diagram (HFE-D). Stochastic Environmental Research and Risk Assessment, 30(5), 1473-1484.

Ayenew T (1998) The Hydrogeological system of the Lake District basin, central main Ethiopian Rift. Publ. no. 64, PhD Thesis, ITC, Enschede, The Netherlands.

Ayenew T (2005) Major ions composition of the groundwater and surface water systems and their geological and geochemical controls in the Ethiopian volcanic terrain. SINET. Ethiopian J. Sci. 28 (2), 171-188.

Ayenew T, Fikre S, Wisotzky F, Demlie M, Wohnlich S (2009) Hierarchical cluster analysis of hydrochemical data as a tool for assessing the evolution and dynamics of groundwater across the Ethiopian Rift. Int $\mathbf{J}$ Phys Sci 4(2):76-90.

Ayenew T, Demlie M, Wohnlich S (2008) Hydrogeological framework and occurrence of groundwater in the Ethiopian aquifers. J. African Earth Sci. 52, 97-113. doi:10.1016/j.jafrearsci.2008.06.006.

Babiker IS, Mohamed MAA, Hiyama T (2007) Assessing groundwater quality using GIS. Water Resour. Manag. 214, 699-715. http://dx.doi.org/10.1007/s11269-006-9059-6.

Barringer JL, Reilly PA (2013). Arsenic in groundwater: A summary of sources and the biogeochemical and hydrogeologic factors affecting arsenic occurrence and mobility. In Current Perspectives in Contaminant Hydrology and Water Resources Sustainability; Paul, B., Ed.; InTechOpen: London, UK; pp. 82-116

Bauder TA, Waskom RM, Sutherland PL, Davis JG (2011) Irrigation water quality criteria. Colorado State University Extension Publication, Crop series/irrigation. Fact sheet no. 0.506,4 pp.

Baykov BD, Stoyanov MP, Gugova ML (1996) Cadmium and lead bioaccumulation in male chickens for high food concentrations. Toxicol. Environ. Chem. 54,155-159.

Benvenuti M, Carnicelli S, Belluomini G, Dainelli N, Di Grazia S, Ferrari GA, Iasio C, Sagri M, Ventra D, Atnafu B, Kebede S (2002) The Ziway-Shala basin (Main Ethiopian Rift, Ethiopia): a revision of basin evolution with special reference to the late quaternary. J. African Earth Sci. 35, 247-269.

Bianchini G, Brombin V, Marchina C, Natali C, Godebo TR, Rasini A, Salani GM (2020). Origin of Fluoride and Arsenic in the Main Ethiopian Rift Waters. Minerals. 10(5):453. https://doi.org/10.3390/min10050453.

Boateng TK, Opoku F, Acquaah SO, Akoto O (2016) Groundwater quality assessment using statistical approach and water quality index in Ejisu- Juaben municipality, Ghana. Environ. Earth Sci. 75, 489. 
Boccaletti M, Bonini M, Mazzuoli R, Abebe B, Piccardi L, Tortorici L (1998) Quaternary oblique extensional tectonics inthe Ethiopian Rift (Horn of Africa). Tectonophysics 287:97-116. doi:10.1016/S00401951(98)80063-2.

Bopp SK, Barouki R, Brack W, Dalla Costa S, Dorne JLCM, Drakvik PE, Faust M, Karjalainen TK, Kephalopoulos S, van Klaveren J, Kolossa-Gehring M, Kortenkamp A, Lebret E, Lettieri T, Nørager S, Rüegg J, Tarazona JV, Trier X, van de Water B, van Gils J, Bergman Å (2018) Current EU research activities on combined exposure to multiple chemicals. Environ. Int. 120, 544-562. https://doi.org/10.1016/j.envint.2018.07.037.

Boswinkel JA (2000) Information Note, International Groundwater Resources Assessment Centre (IGRAC), Netherlands Institute of Applied Geoscience, Netherlands. In: UNEP (2002), Vital Water Graphics - An Overview of the State of the World's Fresh and Marine Waters, UNEP, Nairobi, Kenya.

Brugge D, Buchner V (2011) Health effects of uranium: new research findings Rev. Environ. Health, 26 (2011), pp. 231-249.

Brown RM, McCleiland NJ, Deininger RA, O'Connor MF (1972) A water quality index-crossing the psychological barrier. In: Proceedings of the International Conference on Water Pollution Research, Jerusalem, 18-24 June 1972, pp. 787-797.

Brunt R, Vasak L, Griffioen J (2004) Fluoride in groundwater: probability of occurrence of excessive concentration on global scale, IGRAC.

Buschmann J, Berg M, Stengel C, Winkel L, Sampson ML, Trang PTK, Viet PH (2008) Contamination of drinking water resources in the Mekong delta flood plains: arsenic and other trace metals pose serious health risks to population. Environ. Int.34, 756-764.

Chernet T (1982) Hydrogeology of the lakes region, Ethiopia (Lakes Ziway, Langano, Abitata, Shalla and Awassa). In: The provisional military government of socialist Ethiopia-ministry of mines and energy. Ethiopian Institute of Geological Surveys, Addis Ababa, Ethiopia, 97 pp.

Chernet T, Travi Y, Valles V (2001) Mechanism of degradation of the quality of natural water in the lakes region of the Ethiopian Rift Valley. Water Res 35:2819-2832.

Cunningham WP, Saigo BW (1997). Environmental Science: A Global Concern. Wm. C. Brown Publisher, New York, USA. Pages: 389.

Dainelli N, Benvenuti M, Sagri M (2001) Geological map of the Ziway-Shala lakes basin (Ethiopia). 1:250,000, Italian Ministry for University and Scientific and Technological Research (MURST).

Darling G, Gizaw B, Arusei M (1996) Lake-groundwater relationships and fluid-rock interaction in the East African Rift Valley: isotopic evidence. J. African Earth Sci. 22, 423-430.

Darvishi G, Kootenaei FG, Ramezani M, Lotfi E, Asgharnia H (2016) Comparative investigation of river water quality by OWQI, NSFWQI and Wilcox indexes (case study: The Talar River-IRAN). Archives of Environmental Protection, 42(1), 41-48.

Deshpande SM, Aher KR (2012) Evaluation of Groundwater Quality and its Suitability for Drinking and Agriculture use in Parts of Vaijapur, District Aurangabad, MS, India, Jour. Chem. Sci., 2(1), pp. 25-31. 
Di Paola GM (1972) The Ethiopian Rift Valley (between $7^{\circ} 00^{\prime}$ and $8^{\circ} 40^{\prime}$ lat. north). Bulletin Vulcanology 36, $517-$ 560.

Di Paola GM, Seife MB, Arno V (1993) The Kella horst: its origin and significance in crustal attenuation and magmatic processes in the Ethiopian Rift Valley. In: Geology and Mineral Resources of Somalia and Surrounding Regions, Ist. Agronom. Oltremare, Firenze, Relaz. Monograf, 113, pp. 323-338.

Domenico PA, Schwartz FW (1990) Physical and chemical hydrogeology. Wiley, New York, pp 410-420.

Doneen LD (1964) Water quality for agriculture. Department of Irrigation, University of California, Davis.

Eaton EM (1950) Significance of carbonate in irrigation water. Soil Science, 69, 12-133.

EU Directive 98/83/EC (1998) Council Directive of 3 November 1998 on the quality of water intended for human consumption. Official Journal of the European Union L 330, 32 (5.12.1998.).

Erikson KM, Aschner M (2003) Manganese neurotoxicity and glutamate-GABA interaction. Neurochemistry International, 43, 475.

Feenstra L, Vasak L, Griffioen J (2007) Fluoride in groundwater: Overview and evaluation of removal methods". International Groundwater Resources Assessment Centre Report nr. SP, (1).

Fienen, M. N., Arshad, M. (2016) The international scale of the groundwater issue. In: Integrated Groundwater Management: Concepts, Approaches and Challenges, pp. 21-48. doi: 10.1007/978-3-319-23576-9_2

Firdissa M (2019) Estimation of groundwater recharge by using hydrological modelling: application to Lake Ziway watershed, Ethiopian Rift. MSc. Thesis Addis Ababa Science and Technology University, Addis Ababa, Ethiopia, 118 pp.

Firempong C, Nsiah K, Awunyo-Vitor D, Dongsogo J (2013) Soluble fluoride levels in drinking water-a major risk factor of dental fluorosis among children in Bongo community of Ghana". Ghana medical journal, (47), 1623.

Freeze RA, Cherry JA (1979) Groundwater. Prentice Hall, Englewood Cliffs.

Frisbie SH, Mitchell EJ, Mastera LJ, Maynard DM, Yusuf AZ, Siddiq MY, Ortega R, Dunn RK, Westerman DS, Bacquart T, Sarkar B (2009) Public health strategies for western Bangladesh that address arsenic, manganese, uranium, and other toxic elements in drinking water. Environ. Health Perspect. 117 (3), 410-416.

Gbadebo AM (2005) Arsenic pollution in aquifers located within limestone areas of Ogun State, Nigeria. In Natural Arsenic in Groundwater: Proceedings of the Pre-Congress Workshop "Natural Arsenic in Groundwater", 32nd International Geological Congress, Florence, Italy, 18-19 August 2004 (pp. 85-92). CRC Press.

Gaillardet J, Viers J, Dupré B (2003) Trace elements in river waters. Treatise on Geochemistry.5, pp. 225-272.

Garrels RM, Mackenzie FT (1967) Origin of the chemical compositions of some springs and lakes. Equilibrium concepts in natural water systems 67, 222-242.

Gebrehiwot AB, Tadesse N, Jigar E (2011) Application of water quality index to assess suitability of groundwater quality for drinking purposes in Hantebet watershed. Tigray, Northern Ethiopia ISABB Journal of Food and Agriculture Science 1:22-30.

Gibbs RJ (1970) Mechanisms controlling world water chemistry. Science 17, 1088-1090. http://dx.doi.org/10.1126/science.170.3962.1088. 
Gizaw B (1996) The origin of high bicarbonate and fluoride concentrations in waters of the Main Ethiopian Rift Valley, East African Rift system. J. Afr. Earth Sci. 22 (4), 391-402.

Halcrow (2008) Rift Valley Lakes integrated natural resources development master plan. Ethiopian Valleys Development Studies Authorities, Ministry of Water Resources, Addis Ababa, Ethiopia.

Haji M, Wang D, Li L, Qin D, Guo Y (2018) Geochemical Evolution of Fluoride and Implication for F- Enrichment in Groundwater: Example from the Bilate River Basin of Southern Main Ethiopian Rift. Water 10, 1799. https://doi.org/10.3390/w10121799.

Herojeet R, Rishi MS, Lata R, Sharma R (2016) Application of environ metrics statistical models and water quality index for groundwater quality characterization of alluvial aquifer of Nalagarh Valley, Himachal Pradesh, India. Sustainable Water Resources Management, 2(1), 39-53.

Homoncik SC, MacDonald AM, Heal KVÓ, Dochartaigh, BÉ, Ngwenya BT (2010). Manganese concentrations in Scottish groundwater. Science of The Total Environment, 408(12), 2467-2473. doi:10.1016/j.scitotenv.2010.02.017.

IPCC (2013) Climate change 2013: the physical science basis. In: Contribution of Working Group I to the Fifth Assessment Report of the Intergovernmental Panel on Climate Change. Cambridge University Press, Cambridge, United Kingdom and New York, NY, USA, pp. 1535.

Jacks G, Bhattacharya P, Chaudhary V, Singh KP (2005) Controls on the genesis of some high-fluoride groundwaters in India. App. Geochem, v.20, pp.221-228.

Jaishankar M, Mathew BB, Shah MS, Gowda KRS (2014) Bio-sorption of Few Heavy Metal Ions Using Agricultural Wastes. Journal of Environment Pollution and Human Health 2(1): 16.

Jarvie HP, Whitton BA, Neal C (1998) Nitrogen and phosphorus in east coast British rivers: speciation, sources and biological significance. Sci. Total Environ. 210/211, 79-109.

Kassa N (2007) Groundwater resources and management issues in Central Ethiopian Rift. Unpublished MSc thesis, Addis Ababa University, Ethiopia, pp 128.

Kawo NS, Karuppannan S (2018) Groundwater quality assessment using water quality index and GIS technique in Modjo River Basin, central Ethiopia. Journal of African Earth Sciences, 147, 300-311. https://doi.org/10.1016/j.jafrearsci.2018.06.034.

Kazmin V, Seife MB, Nicoletti N, Petruccini C (1980) Evolution of the Northern Part of the Ethiopian Rift. In: Geodynamic Evolution of the Afro-Arabic Rift System, Accad. Naz. Lincei, Roma, Atti Convegni, 47, pp. $275-292$.

Kebede S, Travi Y, Stadler S (2010) Groundwaters of the Central Ethiopian Rift: diagnostic trends in trace elements, ${ }^{18} \mathrm{O}$ and major elements. J Environ Earth Sci 61:1641-1655.

Keshavarzi B, Moore F, Esmaeili A, Rastmanesh F (2010) The source of fluoride toxicity in Muteh area, Isfahan, Iran. Environmental Earth Sciences, 61(4), 777786.https://doi.org/10.1007/s12665-009-0390-0.

Ketata-Rokbani M, Gueddari M, Bouhlila R (2011) Use of geographical information system and Water Quality Index to assess groundwater quality in El Khairat Deep Aquifer (Enfidha, Tunisian Sahel). Iran J Energy Environ 2(2):133-144. 
Khozyem H, Hamdan A, Tantawy AA, Emam A, Elbadry E (2019) Distribution and origin of iron and manganese in groundwater: case study, Balat-Teneida area, El-Dakhla Basin, Egypt. Arab J Geosci 12, 523. doi.org/10.1007/s12517-019-4689-1.

Kloos H, Tekle-Haimanot R (1999) Distribution of fluoride and fluorosis in Ethiopia and prospects for control. Tropical Medicine \& International Health 4, 355e364.

Kortenkamp A, Faust M (2018) Regulate to reduce chemical mixture risk. Science 361, $224-226$. https://doi.org/10.1126/science.aat9219.

Kumar M, Ramanathan AL, Rao MS, Kumar B (2006) Identification and evaluation of hydrogeochemical processes in the groundwater environment of Delhi, India. J Environ Geol 50:1025-1039.

Li P, Wu J, Qian H (2013) Assessment of groundwater quality for irrigation purposes and identification of hydrogeochemical evolution mechanisms in pengyang county, China. Environ. Earth Sci. 69 (7), 22112225.http://dx.doi.org/10.1007/s12665-012-2049-5.

McMahon PB, Belitz K, Reddy JE, Johnson TD (2019). Elevated Manganese Concentrations in United States Groundwater, Role of Land Surface-Soil-Aquifer Connections. Environ Sci Technol. 53, 29-38. doi: 10.1021/acs.est.8b04055.

Mechal A, Birk S, Dietzel M, Leis A, Winkler G, Mogessie A, Kebede S (2017) Groundwater flow dynamics in the complex aquifer system of Gidabo River Basin (Ethiopian Rift): a multi-proxy approach. Hydrogeol. J. 25, 519-538. http://dx.doi. org/10.1007/s10040-016-1489-5.

Mesele, Y., Mechal, A. Hydrochemical characterization and quality assessment of groundwater in Meki River Basin, Ethiopian Rift. Sustain. Water Resour. Manag. 6, 117 (2020). https://doi.org/10.1007/s40899-020-00471-y.

Merla, G, Abbate E, Azzaroli A, Bruni P, Canuti P, Fazzuoli M, Sagri M, Tacconi P (1979) A Geological map of Ethiopia and Somalia, and comment. CNR, Firenze.

Meireles ACM, Andrade EMd, Chaves LCG, Frischkorn H, Crisostomo LA (2010) A new proposal of the classification of irrigation water. Revista Ciencia Agron^omica 41:349-57. doi: 10.1590/S180666902010000300005.

Mjengera H, Mkongo G (2003) Appropriate deflouridation technology for use in flourotic areas in Tanzania". Physics and Chemistry of the Earth, Parts A/B/C, (28), 2003, 1097-1104.

Milvy P, Cothern R (1990) Scientific background for the development of regulations for radionuclides in drinking water. In: Cothern, R., Rebers, P. (Eds.), Radon, Radium, and Uranium in Drinking Water, pp. 1-16.

Mohr PA (1962) The Ethiopian Rift System. Bulletin of Geophysics Observatory Addis Ababa 5, 33-62.

Mohammed MN (2011) Quality assessment of Tigris river by using water quality index for irrigation purpose. Eur J Sci Res 57:15-28.

Oyem HH, Oyem IM Usese AI (2015) Iron, manganese, cadmium, chromium, zinc and arsenic groundwater contents of Agbor and Owa communities of Nigeria. Springer Plus 4, 104. doi.org/10.1186/s40064-015-0867-0

Ocampo-Duque W, Osorio C, Piamba C, Schuhmacher M, Domingo JL (2013) Water quality analysis in rivers with non-parametric probability distributions and fuzzy inference systems: application to the Cauca River, Colombia. Environment International, 52, 17-28. doi:10.1016/j.envint.2012.11.007. 
Oromia Water Works Design and supervision Enterprise (OWWDSE) (2016) Geological Investigations for Impact Assessment of Water Resources Exploitation on Lake Ziway, Addis Ababa, Ethiopia, 26 pp.

Parvez F, Chen Y, Brandt-Rauf PW, Bernard A, Dumont X, Slavkovich V (2008) Nonmalignant respiratory effects of chronic arsenic exposure from drinking water among never-smokers in Bangladesh. Environ Health Perspect; 116 (2):190-195.

Pascual-Ferrer J, Pérez-Foguet A, Codony J, Raventós E, Candela L (2014) Assessment of water resources management in the Ethiopian Central Rift Valley: environmental conservation and poverty reduction. International Journal of Water Resources Development, 30 (3), 572-587. doi: 10.1080/07900627.2013.843410.

Peter KH (2009) Defluoridation of high fluoride waters from natural water sources by using soils rich in bauxite and kaolinite". Journal of Engineering and Applied Sciences, (4), 240-246.

Piper AM (1944) A graphic procedure in the chemical interpretation of water analysis. Am. Geophys. Union Trans. 25, 914-923.

Rafique T, Naseem S, Usmani HT, Bashir E, Farooque KA, Bhanger MI (2009).Geochemical factors controlling the occurrence of high fluoride groundwater in the Nagar Parkar area, Sindh, Pakistan. J. Hazard. Mater. 171 (13), 424-430.

Raghunath HM (1987) Ground Water: Hydrogeology, Ground Water Survey and Pumping Tests, Rural Water Supply and Irrigation Systems. New Age International (P) Ltd. Publishers ISBN-10: 0470206985.

Rajankar PN, Tambekar DH, Wate SR (2010) Groundwater quality and water quality index at Bhandara District. Environ Monit Assess 179:619-625. doi:10.1007/s10661-010-1767-y.

Rajmohan N, Elango L (2004) Identification and evolution of hydrogeochemical processes in the groundwater environment in an area of the Palar and Cheyyar River Basins, Southern India. Environ Geol 46:47-61.

RamyaPriya R, Elango L (2018) Evaluation of geogenic and anthropogenic impacts on spatio-temporal variation in quality of surface water and groundwater along Cauvery River, India. Environ. Earth Sci. 77 (2). doi.org/10.1007/s12665-017-7176-6.

Rango T, Bianchini G, Beccaluva L, Ayenew T, Colombani N (2009) Hydrogeochemical study in the main Ethiopian Rift: new insights to source and enrichment mechanism of fluoride. Environmental Geology 58, 109-118.

Rango T, Bianchini G, Beccaluva L, Tassinari R (2010) Geochemistry and water quality assessment of central main Ethiopian Rift natural waters with emphasis on source and occurrence of fluoride and arsenic. Journal of African Earth Sciences 57, 479-491.

Rango T, Jeuland M, Whitford GM, Tekle-Haimanot D, Alemayehu B, Assefa G, Wolfe A. (2020) Bone quality in fluoride-exposed populations: A novel application of the ultrasonic method. Bone Reports 12 . doi.org/10.1016/j.bonr.2019.100235.

Rango T, Kravchenko J, Atlaw B, Peter GM, Jeuland M, Merola B, Vengosh A (2012) Groundwater quality and its health impact: an assessment of dental fluorosis in rural inhabitants of the main Ethiopian Rift. Environment International 43, 37-47. 
Rango T, Vengosh A, Dwyer G, Bianchini G (2013) Mobilization of arsenic and other naturally occurring contaminants in groundwater of the Main Ethiopian Rift aquifers, Water Research, http://dx.doi.org/10.1016/j.watres.2013.07.002.

Rango T, Vengosh A, Jeuland M, Tekle-Haimanot R, Weinthal E, Kravchenko J, Paul C, McCornick P (2014)

Fluoride exposure from groundwater as reflected by urinary fluoride and children's dental fluorosis in the Main Ethiopian Rift Valley. Sci. Total Environ. 496, 188-197. http://dx.doi.org/10.1016/j.scitotenv.2014.07.048.

Rango T, Vengosh A, Jeuland M, Whitford GM, Tekle-Haimanot R (2017) Biomarkers of chronic fluoride exposure in groundwater in a highly exposed population. Sci. Total Environ. 596, 1-11.

Ravikumar P, Aneesul Mehmood M, Somashekar RK (2013) Water quality index to determine the surface water quality of Sankey tank and Mallathahalli lake, Bangalore urban district, Karnataka, India. Appl Water Sci 3:247-261. doi:10.1007/s13201-013-0077-2.

Reimann C, Bjorvatn K, Frengstad B, Melaku Z, Tekle- Haimanot R, Siewers U (2003) Drinking water quality in the Ethiopian section of the East African Rift Valley Iedata and health aspects. The Science of the Total Environment 311(1-3), 65-80.

Richards LA (1954) Diagnosis and Improvement of Saline and Alkali Soils. Agri. Handbook 60. U.S. Department of Agriculture, Washington, DC, pp. 160.

Rodriguez de Francisco JC (2008) Preconditions for a payment for environmental services establishment at Central Rift Valley, Ethiopia. MSc. Thesis, Wageningen University.

Saeedi M, Abessi O, Sharifi F, Meraji H (2010) Development of groundwater quality index. Environ Monit Assess $163: 327-335$.

Sahu P, Sikdar PK (2008) Hydrochemical framework of the Aquifer in and around East Kolkata Wetlands, West Bengal, India. Environ Geol 55:823-835.

Saleh A, Al-ruwaih F, Shehata M (1999) Hydrogeochemical processes operating within the main aquifers of Kuwait. Jour. Arid Environ., v.42, pp.195-209.

Saxena VK, Ahmed S (2003) Inferring the chemical parameters for the dissolution of fluoride in groundwater. Environ. Geol, v.43, pp. 731-736.

Schoeller H (1965) Hydrodynamicue lans lekarst. Actes du Colloque de Dubrovnik, IAHS/ UNESCO, Paris, 2-20.

Selvam S, Manimaran G, Sivasubramanian P, Balasubramanian N, Seshunarayana T (2013) GIS-based Evaluation of Water Quality Index of groundwater resources around Tuticorin coastal city, south India. Environ. Earth Sci. 716, 2847-2867. http://dx.doi.org/10.1007/s12665-013-2662-y.

Selden AI, Lundholm C, Edlund B, Hogdahl C, Ek BM, Bergstrom BE, Ohlson CG (2009) Nephrotoxicity of uranium in drinking water from private drilled wells. Environ. Res. 109 (4), 486-494. doi:10.1016/j.envres.2009.02.002

Singh P, Khan I (2011) Ground water quality assessment of Dhankawadi ward of Pune by using GIS. Int. J. Geomatics Geosci. 2, 688-703. 
Singh S, Ghosh NC, Gurjar S, Krishan G, Kumar S, Berwal P (2018) Index-based assessment of suitability of water quality for irrigation purpose under Indian conditions. Environmental Monitoring and Assessment 190 (1), art. no. 29, doi: 10.1007/s10661-017-6407-3.

Smedley P, Kinniburgh G (2017) Molybdenum in natural waters: a review of occurrence, distributions and controls. Applied Geochemistry, 84. 387-432. https://doi.org/10.1016/j.apgeochem.2017.05.008.

Smedley PL, Knudsen J, Maiga D (2007) Arsenic in groundwater from mineralized Proterozoic basement rocks of Burkina Faso. Applied Geochemistry, 22(5), 1074-1092.

Smedley PL, Zhan M, Zhang G, Luo Z (2003) Mobilization of arsenic and other trace elements in fluvio-lacustrine aquifers of the Huhhot Basin, Inner Mongolia, Appl. Geochem., 18(9), 1453-1477.

Smith AH, Goycolea M, Haque R, Biggs ML (1998). Marked increase in bladder and lung cancer mortality in a region of Northern Chile due to arsenic in drinking water. Am J Epidemiol, 147(7):660-669.

Srinivasamoorthy K, Chidambaram M, Prasanna MV, Vasanthavigar M, John PA Anandhan P (2008) Identification of major sources controlling groundwater chemistry from a hard rock terrain —a case study from Mettur taluk, Salem district, Tamilnadu, India. J Earth Syst Sci 117(1):49-58.

Sutadian A, Muttil N, Yilmaz A, Perera B (2016) Development of river water quality indices-a review. Environ. Monit. Assess. https://doi.org/10.1007/s10661-015-5050-0.

Tchounwou PB, Yedjou CG, Udensi UK, Pacurari M, Stevens JJ, Patlolla AK, Noubissi F, Kumar S (2019) State of the science review of the health effects of inorganic arsenic: Perspectives for future research. Environ Toxicol. 34 (2):188-202. doi: 10.1002/tox.22673.

Tekle-Haimanot R (1990) Neurological complication of endemic skeletal fluorosis with special emphasis on rediculomyelopathy. Paraplegia; 28:244 -251.

Tekle-Haimanot R, Fekadu A, Bushra B (1987) Endemic fluorosis in the Ethiopian rift valley. Tropical and Geographical Medicine 39, 209-217.

Tekle-Haimanot R, Melaku Z, Kloos H, Reimann C, Fantaye W, Zerihun L, Bjorvatn K (2006) The geographic distribution of fluoride in surface and groundwater in Ethiopia with an emphasis on the Rift Valley. Sci Total Environ 367:182-190.

Todd DK (1980) Groundwater hydrology, vol 10016, 2nd edn. Wiley, New York, pp 267-315.

UNDP (1973) Geology, geochemistry and hydrology of hot springs of the East African Rift system within Ethiopia. UNDP report DD/SF/ON-11, NY; 300.

US Environmental Protection Agency (USEPA) (2003) Drinking water standards. Office of Drinking Water. US Environmental Protection Agency, Washington, DC.

Vartanian JP, Sala M, Henry M, Wain-Hobson S, Meyerhans A (1999) Manganese cations increase the mutationrateofhumanimmunedeficiencyvirustype1exvivo. Journal of General Virology, 80, 1983.

Vasanthavigar M, Srinivasamoorthy K, Vijayaragavan K, Rajiv Ganthi R, Chidambaram S, Anandhan P, Manivannan R, Vasudevan S (2010) Application of water quality index for groundwater quality assessment: Thirumanimuttar sub-basin, Tamilnadu, India. Environ Monit Assess. doi:10.1007/s10661009-1302-1. 
Wada Y, Wisser D, Bierkens MFP (2014) Global modeling of withdrawal, allocation and consumptive use of surface water and groundwater resources. Earth System Dynamics 5 (1): 15-40. doi: 10.5194/esd-5-15-2014

Wilcox LV (1955) Classification and Use of Irrigation Waters. U.S. Department of Agriculture. Circ, Washington, DC. pp. 969.

WoldeGabriel G, Aronson JL, Walter RC (1990) Geology, geochronology, and Rift basin development in the central sector of the main Ethiopian Rift. Geological Society of America Bulletin 102, 439-458.

WoldeGabriel G, Heiken G, White TD, Asfaw B, Hart WK, Renne PR (2000) Volcanism, tectonism, sedimentation, and the paleoanthropological record in the Ethiopian Rift System. In: McCoy FW, Heiken G (eds) Volcanic hazards and disasters in human antiquity. Geol Soc Am Spec Pap 345:83-99.

World Health Organization (WHO) (2011) Guidelines for drinking-water quality (Fourth ed.p. 541). Geneva: World Health Organization.

WRI, UNEP, UNDP, World Bank (1998) World resources 1998-99: a guide to the global environment - environmental change and human health (English). Washington, D.C.: The World Bank. http://documents.worldbank.org/curated/en/545461468744003084/World-resources-1998-99-a-guide-tothe-global-environment-environmental-change-and-human-health.

WWDSE (2016) Impact Assessment of Water Resources Exploitation on Lake Ziway, Oromia Water Works Design and Supervision Enterprise (WWDSE), Addis Ababa, Ethiopia.

Wu Y, Wang YX, Xie XJ (2014) Occurrence, behavior and distribution of high levels of uranium in shallow groundwater at Datong basin, northern China. Sci. Total Environ.472, 809-817.

Yadav SK, Ramanathan AL, Kumar M, Sabarathinam C (2020) Assessment of arsenic and uranium co-occurrences in groundwater of central Gangetic Plain, Uttar Pradesh, India. Environ Earth Sci 79, 154, https://doi.org/10.1007/s12665-020-8892-x.

Yirgu G, Dereje A, Peccerillo A, Barberio MR, Donati C, Donato P (1999) Fluorine and chlorine distribution in the volcanic rocks from the Gedemsa volcano, Ethiopian Rift Valley. Acta Vulcanologica 11, 169e176.

Zahedi S (2017) Modification of expected conflicts between drinking water quality index and irrigation water quality index in water quality ranking of shared extraction wells using multi criteria decision making techniques. Ecol Indicators 83:368-79. doi:10.1016/j.ecolind.2017.08.017. 

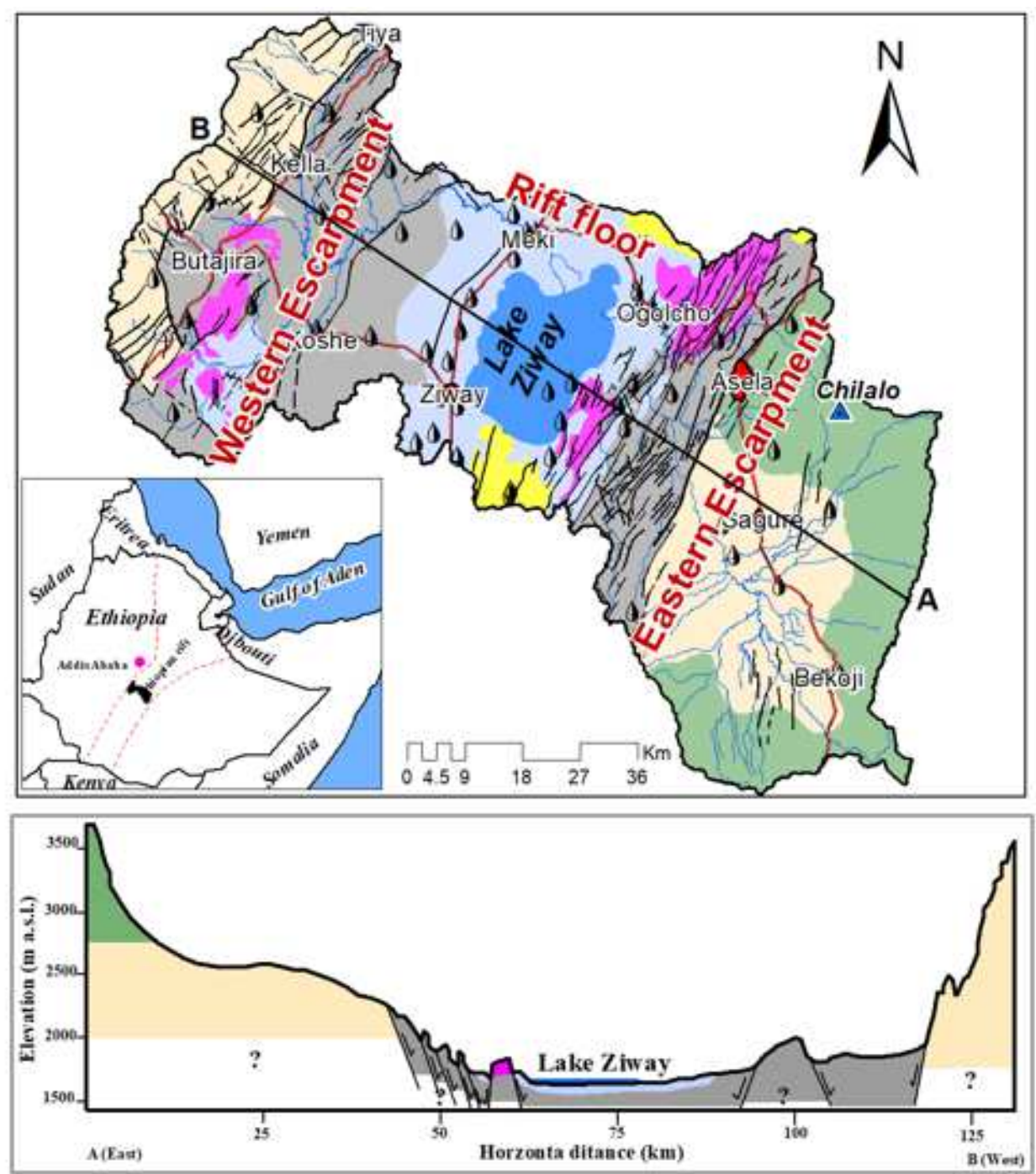

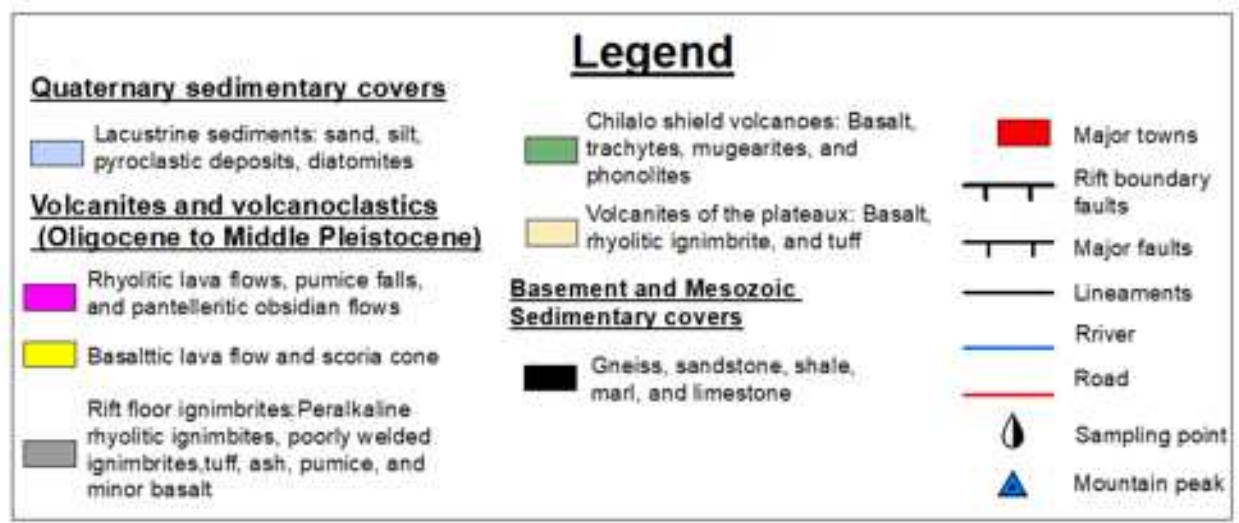

\section{Figure 1}

Location and simplified geological map of the ZLB (compiled from Dainelli et al. 2001; Halcrow 2008). 

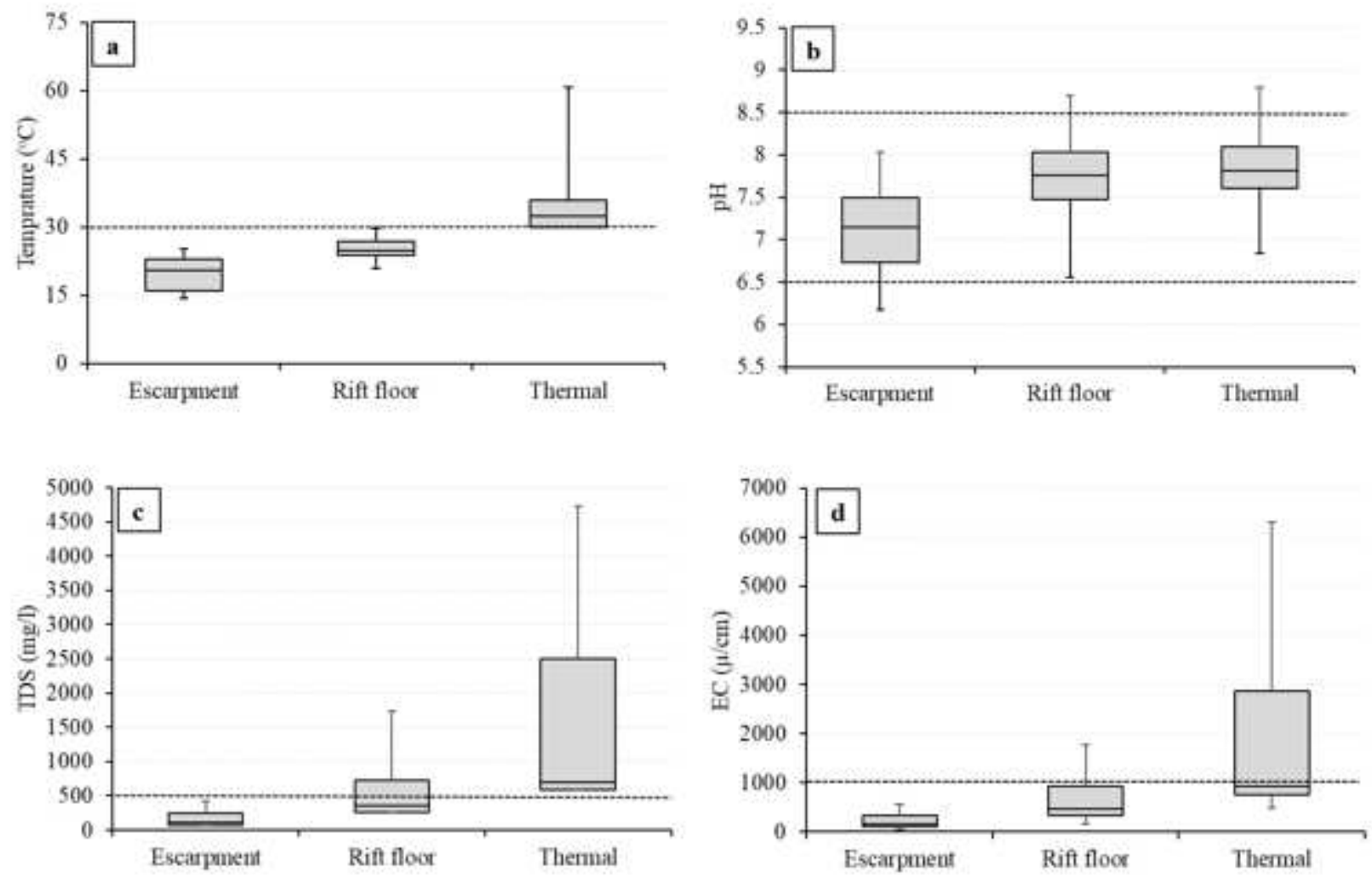

Figure 2

(a-d) Box plot showing the spatial variation in temperature, $\mathrm{pH}, \mathrm{TDS}$, and EC from the escarpment to the rift floor. The broken line represents the "permissible" value (WHO 2011).
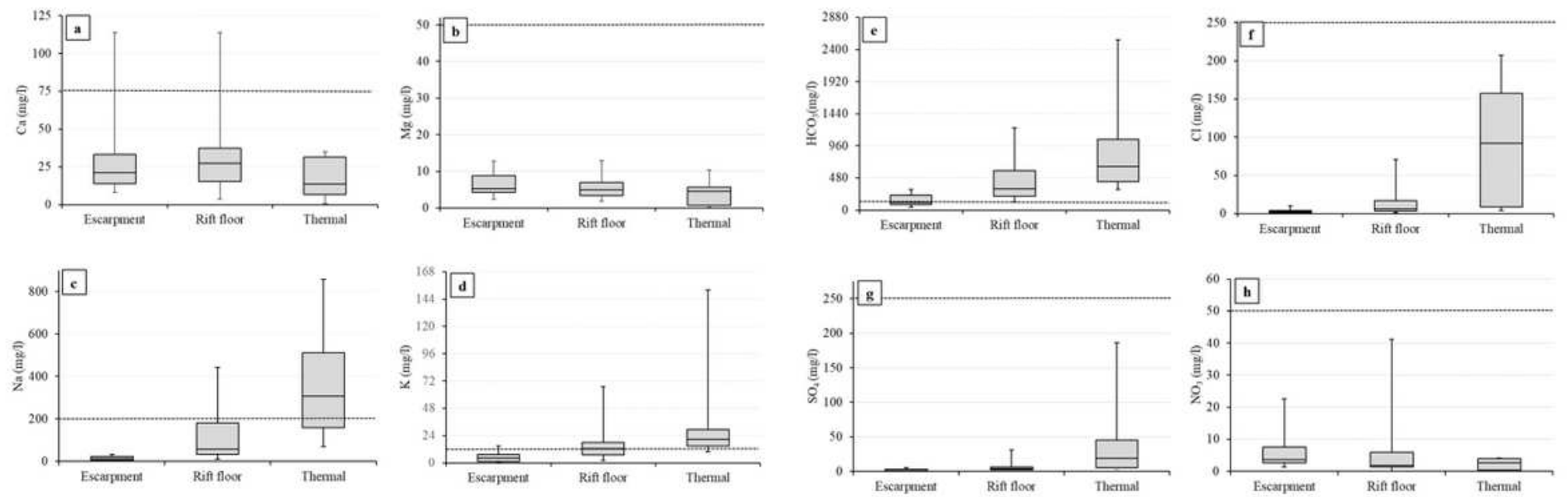

\section{Figure 3}

$(\mathrm{a}-\mathrm{h})$ Box plot showing the spatial variation of major ions (Ca2+, $\mathrm{Mg} 2+, \mathrm{Na}+, \mathrm{K}+, \mathrm{HCO} 3-, \mathrm{Cl}-, \mathrm{SO} 42-$, and NO3-) from the mountains to the rift floor. The broken line represents the "permissible" guideline (WHO 2011). 


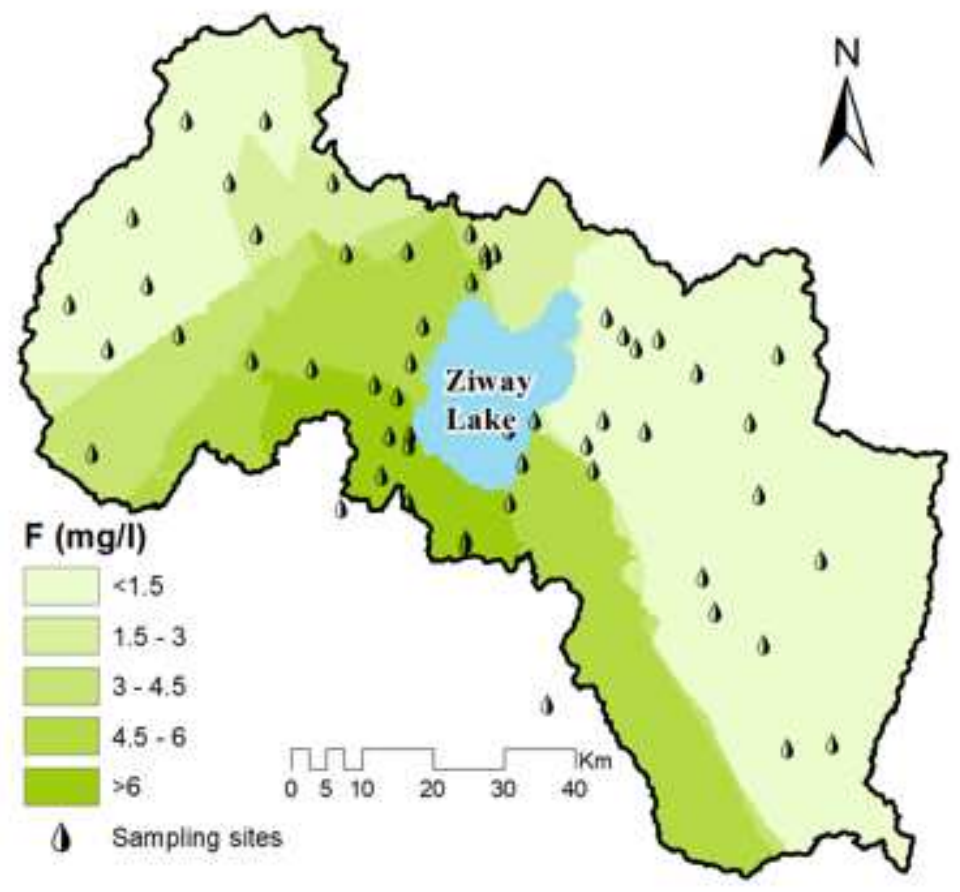

Figure 4

Spatial distribution of F- in the groundwater of ZLB.

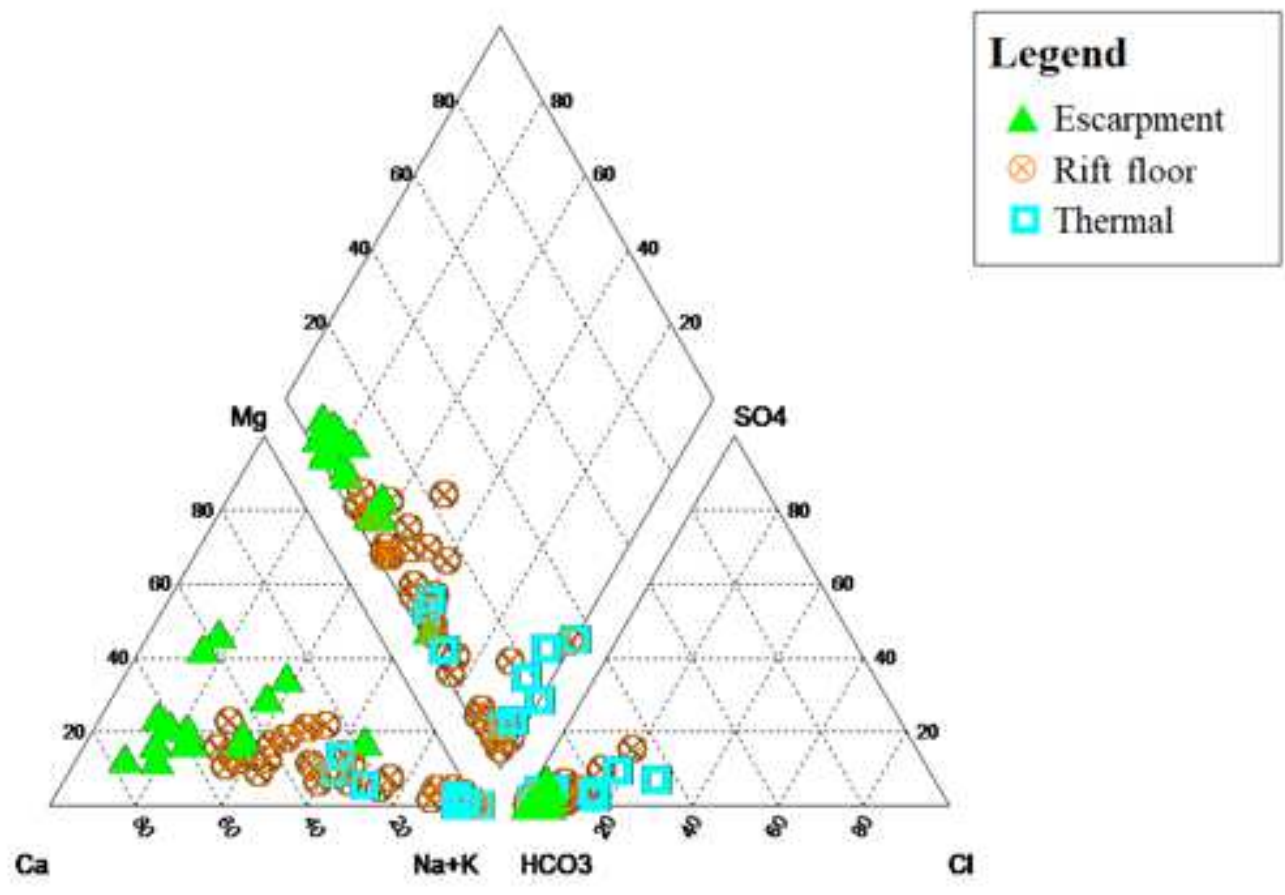

Figure 5

Piper diagram depicting the hydrochemical facies of the groundwater in the study area. 

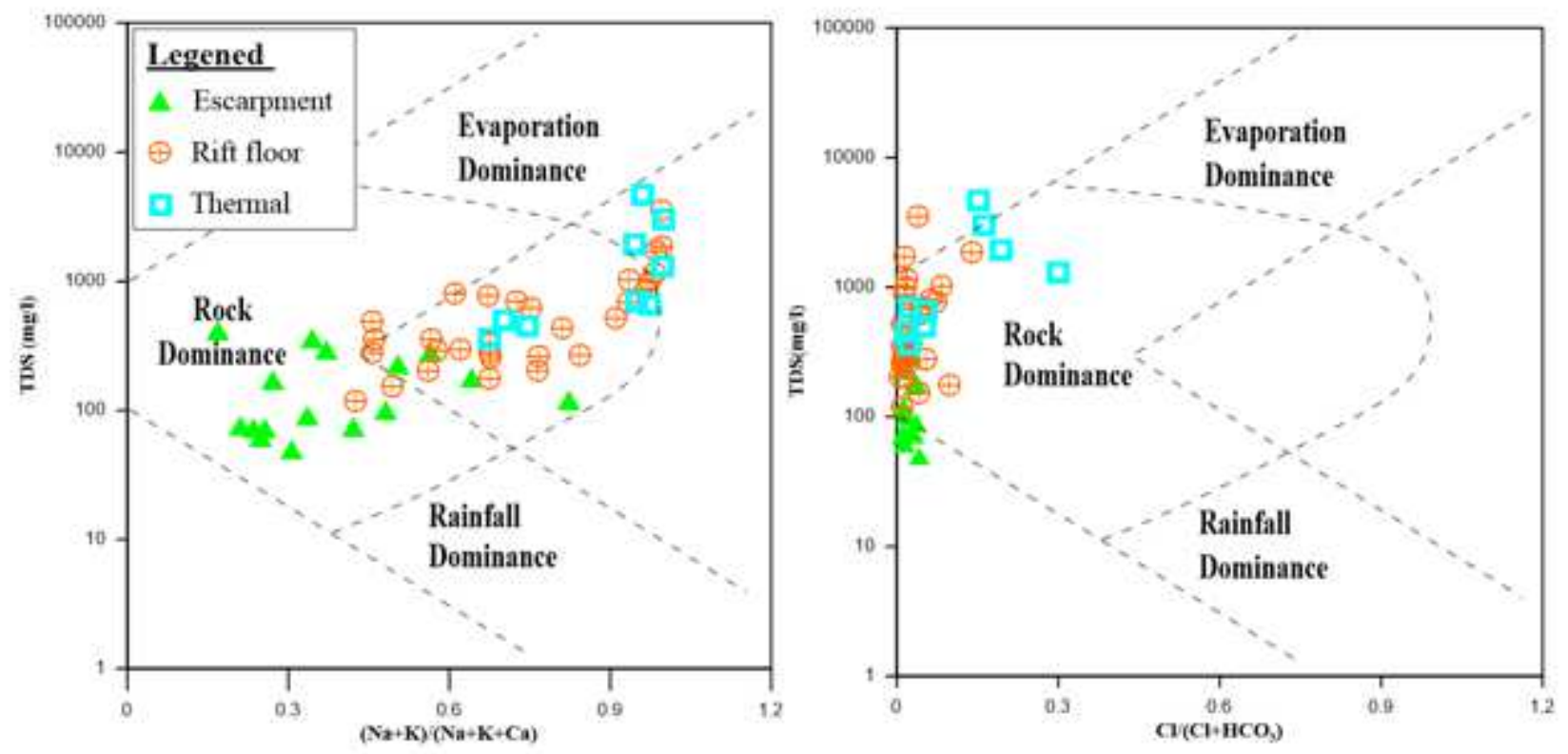

\section{Figure 6}

Gibbs diagram showing prominent processes controlling the chemistry of groundwater in the ZLB.
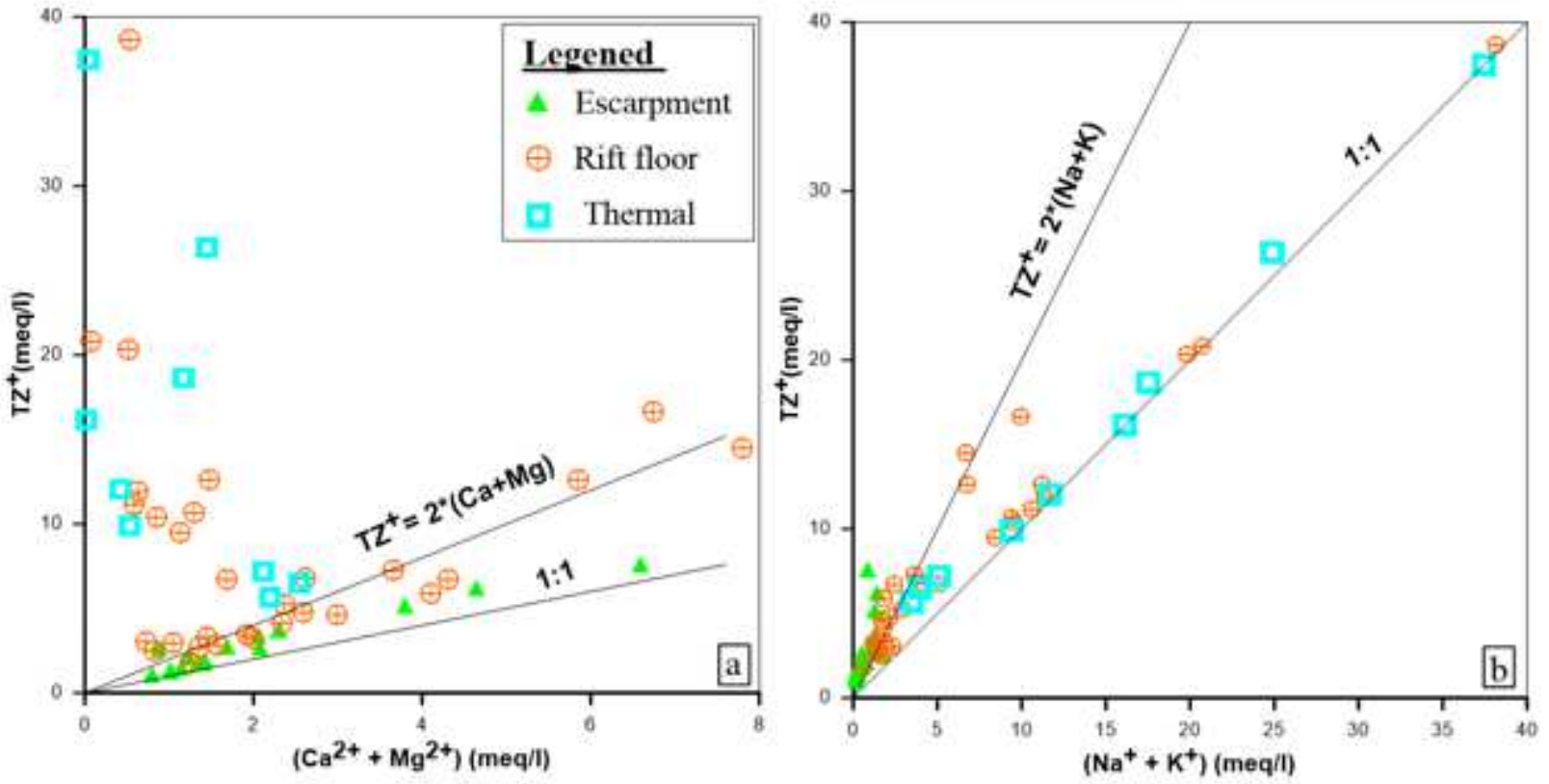

\section{Figure 7}

The relation between $\mathrm{Ca}+\mathrm{Mg}(\mathrm{a})$ and $\mathrm{Na}+\mathrm{K}(\mathrm{b})$ with total cation $(\mathrm{TZ}+)$ in the study groundwater. 


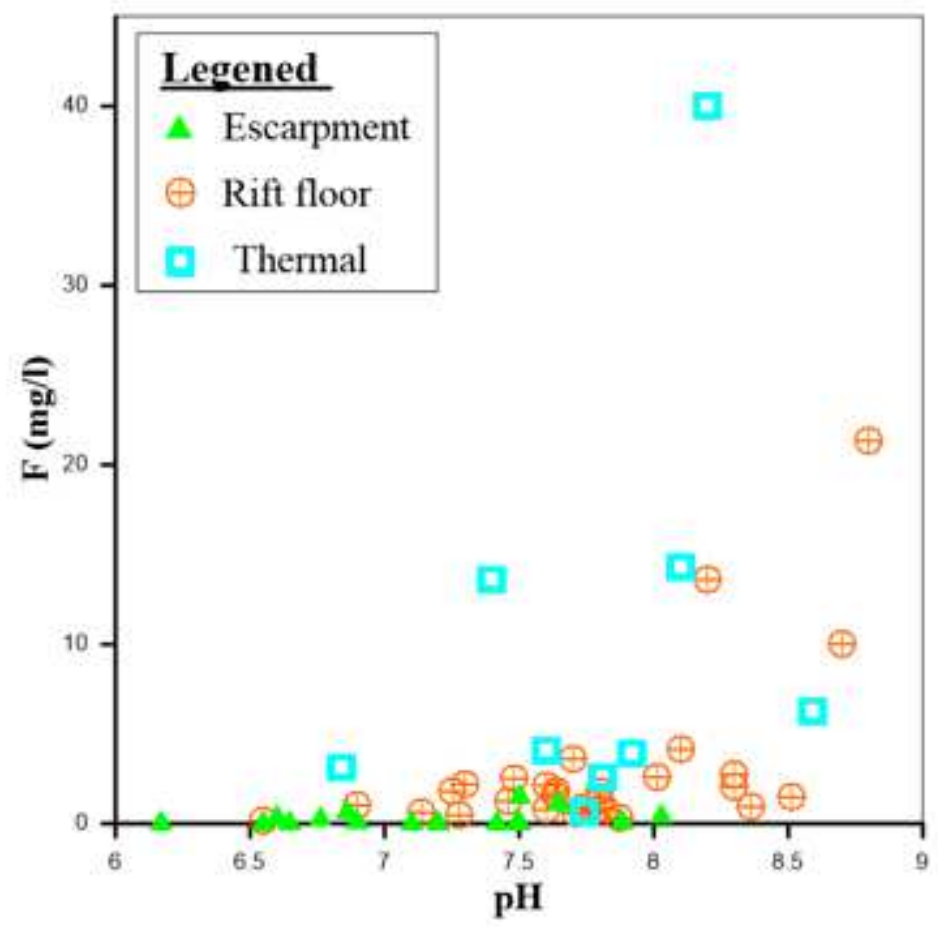

Figure 8

Scatter plot illustrating the relationship between $\mathrm{pH}$ and fluoride concentrations in the groundwater of ZLB.

a

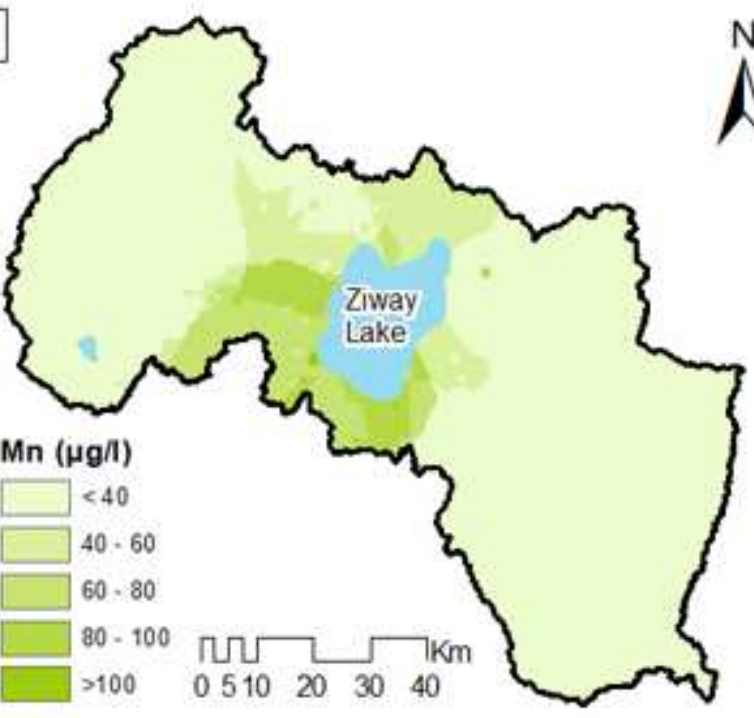

$\sqrt{\mathrm{b}}$
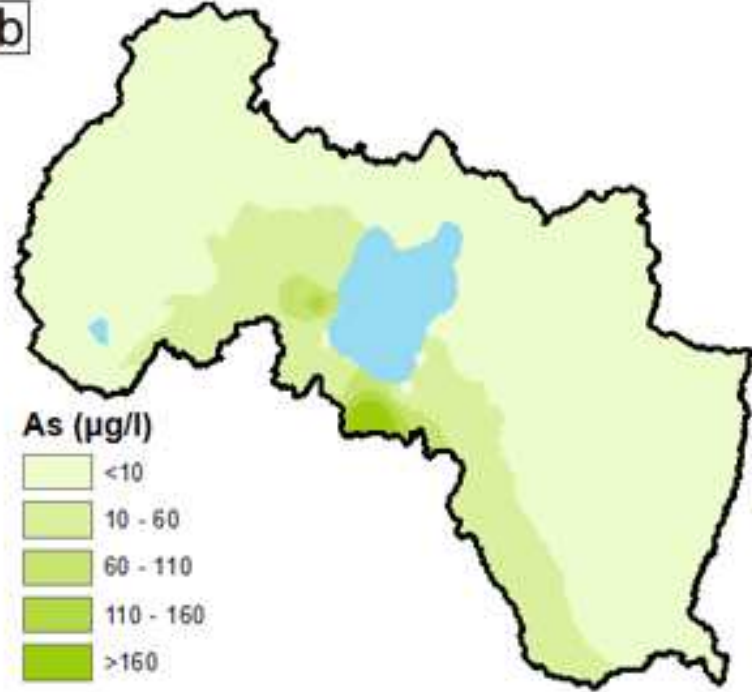

Figure 9

The spatial distribution of the two most frequent toxic elements ( $\mathrm{Mn}(\mathrm{a})$ and $\mathrm{As}(\mathrm{b})$ ) in the study area (see sampling sites in Fig. 1 or 4). 

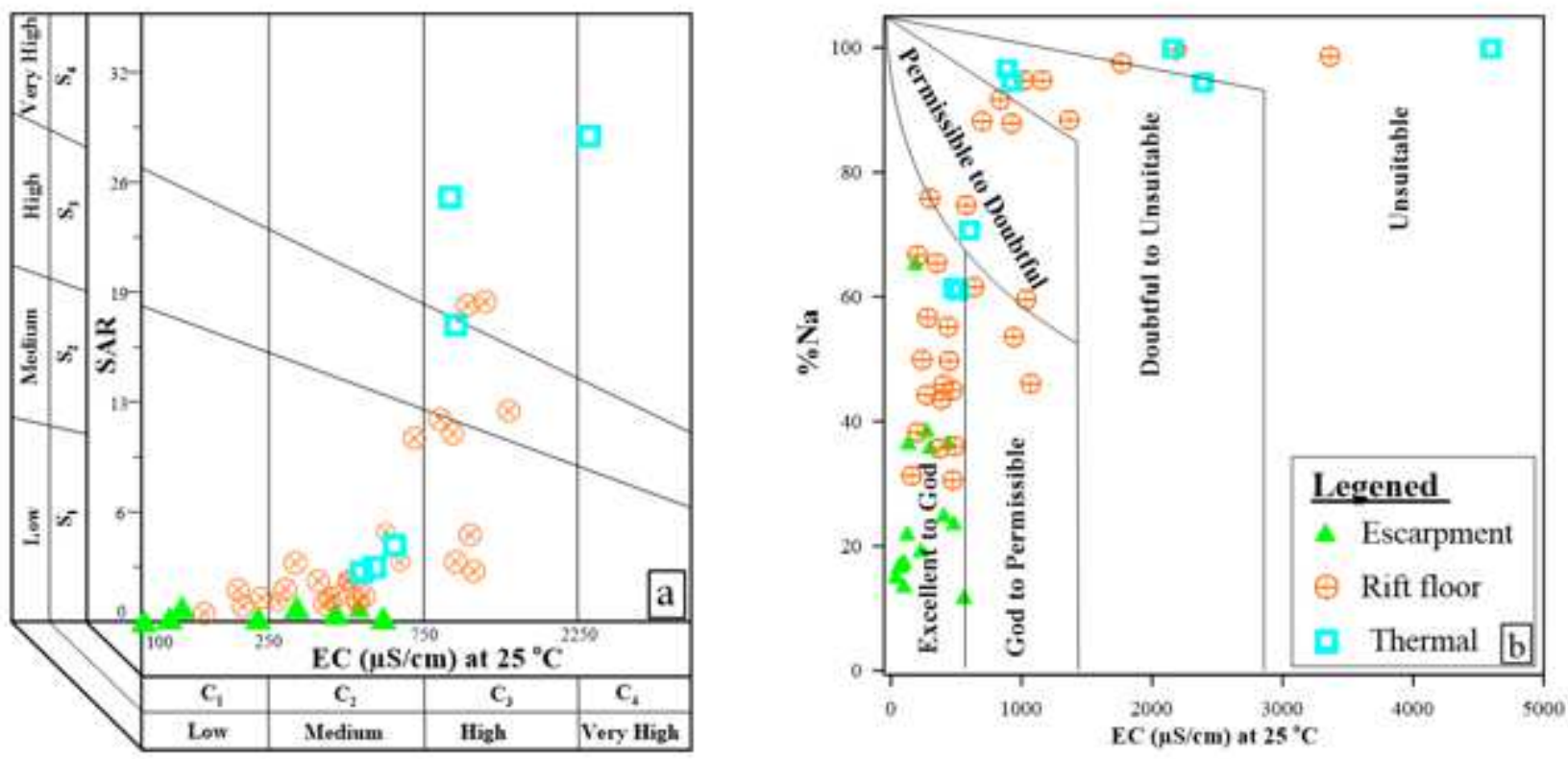

Figure 10

Irrigation water quality assessment based on Wilcox (a) and USSL (b) diagrams.
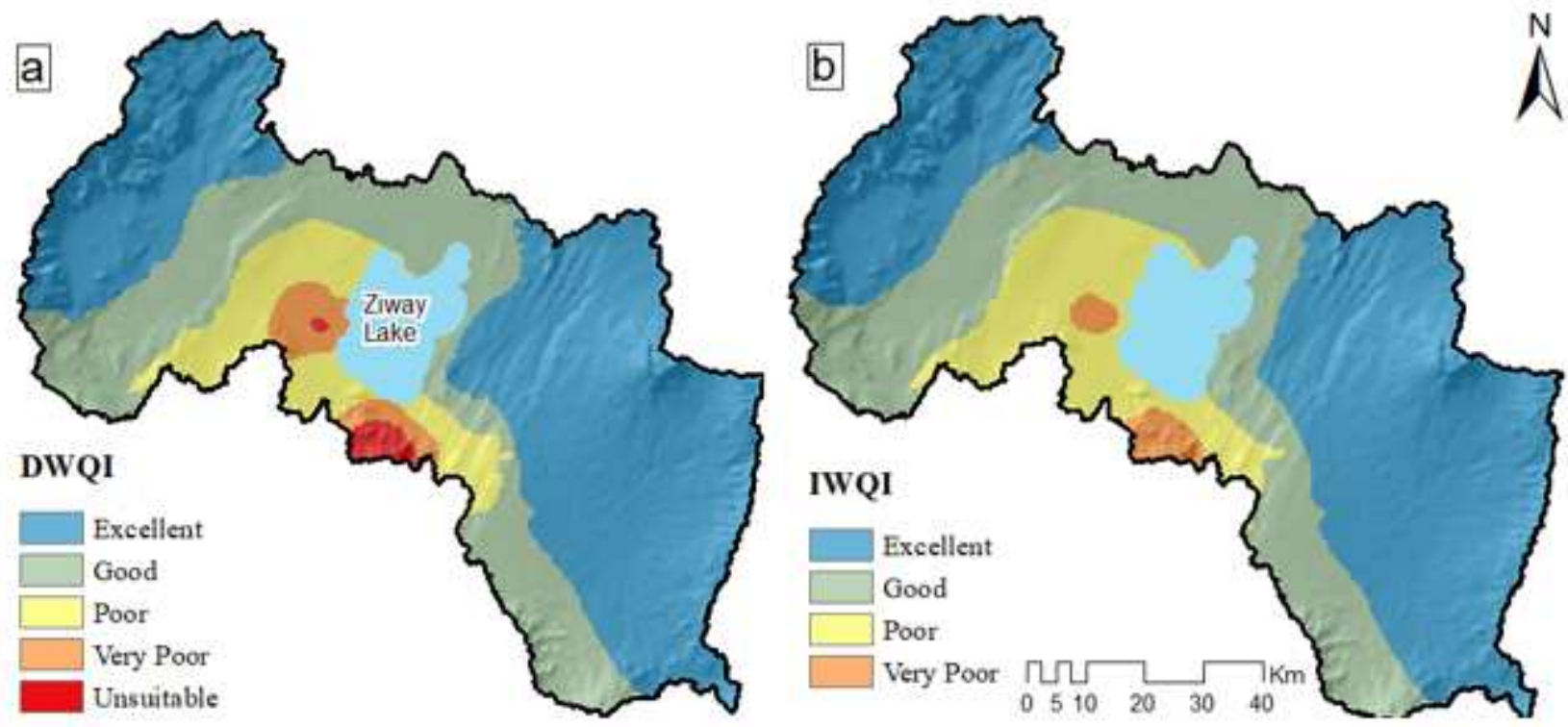

Figure 11

Spatial variation of Drinking (a) and Irrigation (b) Water Quality Index in the ZLB. 